\title{
Feature-Based Molecular Network-Guided Dereplication of Natural Bioactive Products from Leaves of Stryphnodendron pulcherrimum (Willd.) Hochr
}

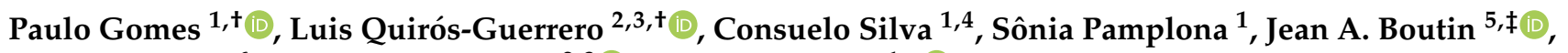 \\ Marcos Eberlin ${ }^{6}$, Jean-Luc Wolfender ${ }^{2,3}{ }^{-1}$ and Milton Silva ${ }^{1, *(1)}$
}

1 Laboratory of Liquid Chromatography, Institute of Exact and Natural Sciences, Federal University of Pará, Belem 66075-110, Brazil; wendergomes@ufpa.br (P.G.); yumikoyoshioka@yahoo.com.br (C.S.); sgpamplona@yahoo.com.br (S.P.)

2 School of Pharmaceutical Sciences, University de Geneva, CMU, Rue Michel-Servet 1, CH-1206 Geneva, Switzerland; Luis.Guerrero@unige.ch (L.Q.-G.); Jean-Luc.Wolfender@unige.ch (J.-L.W.)

3 Institute of Pharmaceutical Sciences of Western Switzerland, University of Geneva, CMU, Rue Michel Servet 1, 1211 Geneva, Switzerland

4 Pharmaceutical Science Post-Graduation Program, Faculty of Pharmacy, Federal University of Pará, Pará 66075-110, Brazil

5 Institut de Recherches Internationales Servier, 50 rue Carnot, 92284 Suresnes, France; ja.boutin.pro@gmail.com

6 MackMass Laboratory, School of Engineering-PPGEMN, Mackenzie Presbyterian University, São Paulo 01302-907, Brazil; marcos.eberlin@mackenzie.br

check for updates

Citation: Gomes, P.;

Quirós-Guerrero, L.; Silva, C.; Pamplona, S.; Boutin, J.A.; Eberlin, M.; Wolfender, J.-L.; Silva, M. Feature-Based Molecular NetworkGuided Dereplication of Natural Bioactive Products from Leaves of Stryphnodendron pulcherrimum (Willd.) Hochr. Metabolites 2021, 11, 281. https://doi.org/10.3390/ metabo11050281

Academic Editor:

Gabriele Capodaglio

Received: 15 February 2021

Accepted: 3 March 2021

Published: 29 April 2021

Publisher's Note: MDPI stays neutral with regard to jurisdictional claims in published maps and institutional affiliations.

Copyright: ( $\odot 2021$ by the authors Licensee MDPI, Basel, Switzerland. This article is an open access article distributed under the terms and conditions of the Creative Commons Attribution (CC BY) license (https:// creativecommons.org/licenses/by/ $4.0 /)$.
* Correspondence: yumilton@yahoo.com.br; Tel.: +55-9132-017-365

+ Equal contribution.

$\ddagger$ Present address: PHARMADEV (Pharmacochimie et Biologie pour le Développement), Université Toulouse 3 Paul Sabatier, Faculté de Pharmacie, 35 Chemin des Maraîchers, CEDEX 9, 31062 Toulouse, France.

\begin{abstract}
Stryphnodendron pulcherrimum is a species known to have a high content of tannins. Accordingly, its preparations are used in southern Pará, Brazil, for their anti-inflammatory and antimicrobial activities, but so far, its chemical profile composition remains essentially unknown. We herein describe the compounds present in a hydro-acetonic extract from S. pulcherrimum leaves as revealed by dereplication via ultra-high performance liquid chromatography coupled to high-resolution mass spectrometry. The data were combined with spectral organization, spectral matching through the Global Natural Products Social platform, in silico annotation and taxonomical ponderation. Several types of phenolic compounds were identified such as gallic acids, flavan-3-ols and flavone-like compounds. From these, 5 have been recently reported by our group, whereas 44 are reported here for the first time in this tree species, and 41 (out of 49) for this genus. The results highlight the possible role of Stryphnodendron pulcherrimum as a renewable source for natural bioactive products with potential pharmaceutical applications.
\end{abstract}

Keywords: Stryphnodendron; UHPLC-MS/MS; molecular network; dereplication

\section{Introduction}

Stryphnodendron pulcherrimum (Wild.) Hochr species belong to the Fabaceae family and are usually found in the Amazon and Atlantic forests and in the southern part of Bahia state in Brazil. This tree is commonly known in Brazil as "fake-barbatimão", paricazinho, paricarana, jubarbatimão, juerana-branca or cowboy [1]. In southern Pará, its leaves, fruits and bark are used in traditional medicine, being particularly indicated as an anti-inflammatory agent [2]. A recent study [3] of several plant extracts from the Amazon region highlighted the antimicrobial activity of the aerial parts of S. pulcherrimum against strains of Enterococcus faecalis, proposing this plant as a potential source of natural bioactive compounds. 
The use of natural products as drugs or as inspiration to develop new active principles currently plays an important role in the pharmaceutical industry [4]. This role has motivated researchers aiming to develop new strategies to study plant metabolites in a more comprehensive and rational manner. Plants offer vast, renewable and sustainable sources of new pharmacophores with chemical structures exquisitely designed for biological functions, and many of these are yet to be discovered [4-6].

The comprehensive chemical description of complex natural mixtures remains as an extremely challenging task [7]. Due to high composition complexity, they often contain several hundreds of compounds of contrasting properties $[8,9]$. This task has been, however, facilitated thanks to the continuous improvements in analytical techniques such as nuclear magnetic resonance (NMR) spectroscopy and liquid chromatography coupled to tandem mass spectrometry (LC-MS/MS) [10-12]. Recent developments of innovative strategies to study metabolites from complex matrices such as the organization of the spectral information using Global Natural Product Social Molecular Networking (GNPS)have also been very useful. This latter methodology is capable of simultaneously visualizing the chemical space from non-targeted mass spectrometry data and identifying compounds through mass spectral matching [13].

Efforts to identify metabolites of Stryphnodendron species have been intense and increasing due to the promising biological activities reported [3,14-29]. Tannins have been found to be their major components, particularly in the "barbatimao" species, and are likely responsible for the reported antimicrobial activities [30,31].

Herein, in the search for bioactive compounds, we used UHPLC-MS/MS combined with feature-based molecular networking-Global Natural Products Social (FBMN-GNPS) and other state-of-the-art bioinformatic tools to further decipher the chemical composition of the hydro-acetonic leaf extract of Stryphnodendron pulcherrimum.

\section{Results}

\subsection{Stryphnodendron Pulcherrimum Extract Characterization by UHPLC-MS/MS}

The hydro-acetonic extract was cleaned up using a C-18 SPE cartridge to remove highly lipophilic compounds such as chlorophylls. It was subjected to UHPLC-MS/MS in the negative ion (NI) mode to favor the ionization of phenolic compounds known to be abundant in plants from the genus. This high-resolution MS analysis using a Qtof analyzer provided nearly accurate molecular masses $\left(\mathrm{MS}^{1}\right)$ and the corresponding fragmentation patterns $\left(\mathrm{MS}^{2}\right.$ ) of the molecular ions [32]. To obtain a molecular network, the MS data were treated using MZmine software [33] and then, the data $\mathrm{MS}^{1}$ and $\mathrm{MS}^{2}$ were uploaded to the GNPS platform [34]. The molecular network (MN) obtained consisted in 284 features (Figure 1). The resulting MN was then subjected to dereplication against experimental MS ${ }^{2}$ data from the GNPS databases, and in silico fragmentation spectra created from a large database of natural products, followed by a re-ranking of the putative identities based on taxonomy [35,36].

According to the dictionary of natural products (DNP, v.29.1,), 42 compounds have been reported in the genus Stryphnodendron. From them, 36 correspond to saponin derivatives, mostly stryphnosides, which have been reported in fruits from Stryphnodendron fissuratum [37,38] and Stryphnodendron coriaceum [39]. The remaining six compounds include polyphenolic derivatives from Stryphnodendron adstringens $[14,15,40]$. Since the working sample is from leaves, not the fruits, an extensive literature research was conducted to create an in-house database (Table S1). It included 74 compounds reported for the Stryphnodendron genus, in different parts of the plants [14-17,23,24,29,40-47]. Based on the molecular formula (MF) and heuristic filtering [48], this database was used to further identify compounds in the extract. 


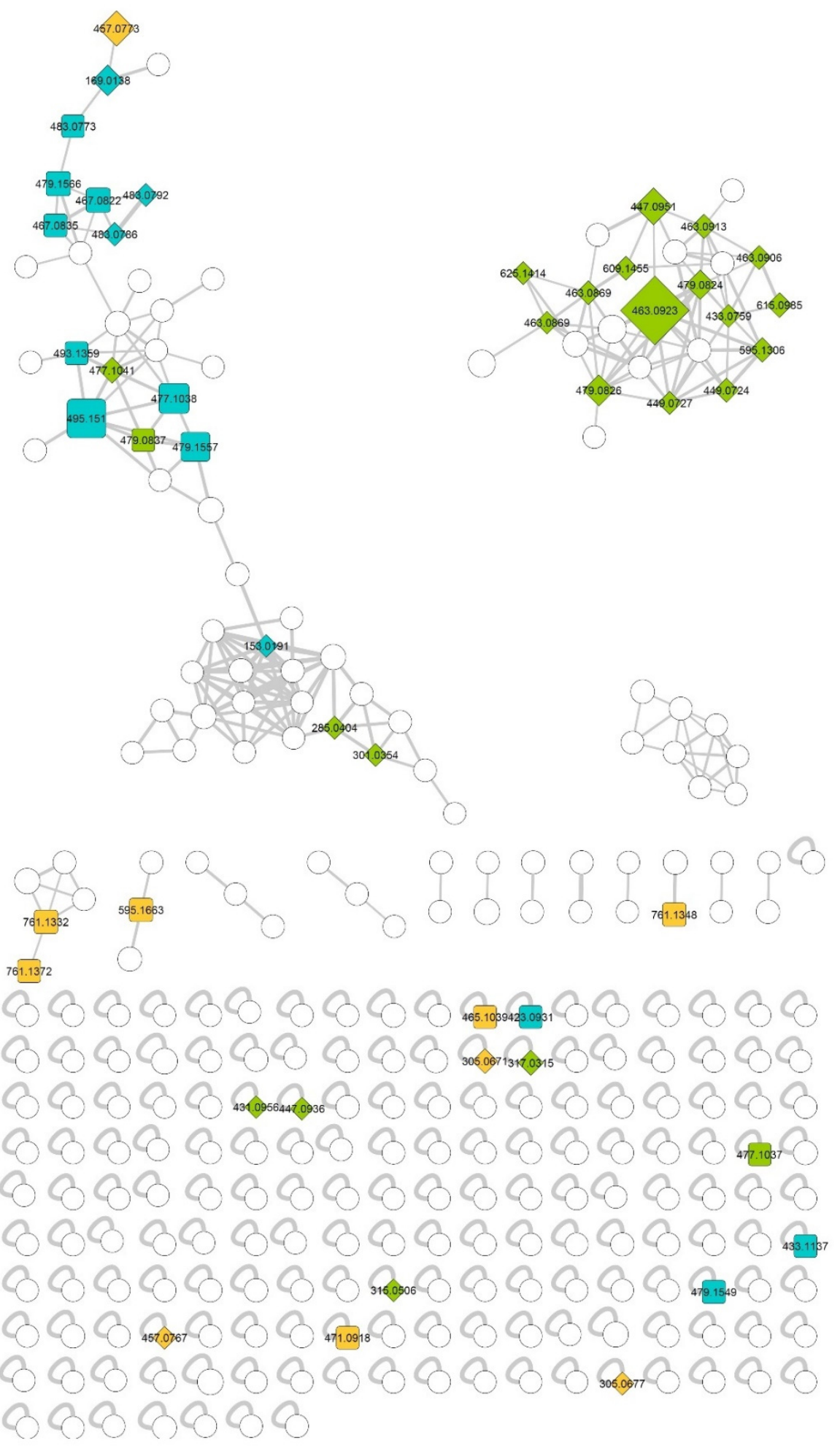

Gallic acid derivatives (G1)

Flavan-3-ol derivatives (G2)

Flavones derivatives (G3)

Figure 1. Molecular network from UHPLC-MS/MS data in the negative ion mode for S. pulcherrimum leaf extract. Numbers inside the nodes correspond to the $m / z$ accurate masses $(D a)$ for the $[\mathrm{M}-\mathrm{H}]^{-}$ 
for each precursor ion. Node size is proportional to the intensity of the ion peaks in the total ion chromatogram. Node colors represent the three different groups: gallic acid derivatives (G1, blue), flavan-3-ol derivatives (G2, orange) and flavone derivatives (G3, green). Rhomboid shapes correspond to a match against an experimental $\mathrm{MS}^{2}$; square shapes are identifications from in silico spectra matching.

After the dereplication process and careful evaluation of the proposed annotations, 49 compounds (1-49) were putatively identified (Table 1 and Figure 2). They were all found to be phenolics. These compounds were subdivided into three groups based on their structural characteristics, independent of their retention times, namely: Group 1 of gallic acid derivatives $(1,2,8-11,14,15,21,25,26,32,38,43,44)$, Group 2 of flavan-3-ol derivatives $(3,4,6,7,12,13,16,18,22,24)$ and Group 3 of flavone derivatives $(5,17,19$, 20, 23, 27-31, 33-37, 39-42, 45-49). Gallic acid (1), gallocatechin (4), (epi)gallocatechin (6), (epi)gallocatechin gallate (13), 3-O-galloyl-4'-O-methylepigallocatechin (24), myricitrin (31), myricetin (42) and luteolin-4'-O-glucoside (45) have been previously reported in the genus Stryphnodendron [14,15,17,23,24,29,41-46,49]. Among them, gallic acid (1), (epi)gallocatechin (6), (epi)gallocatechin gallate (13), myricitrin (31) and myricetin (42) have been reported in S. pulcherrimum [49]. To the best of our knowledge, 44 of these compounds are reported herein for the first time for S. pulcherrimum and 41 for the genus.
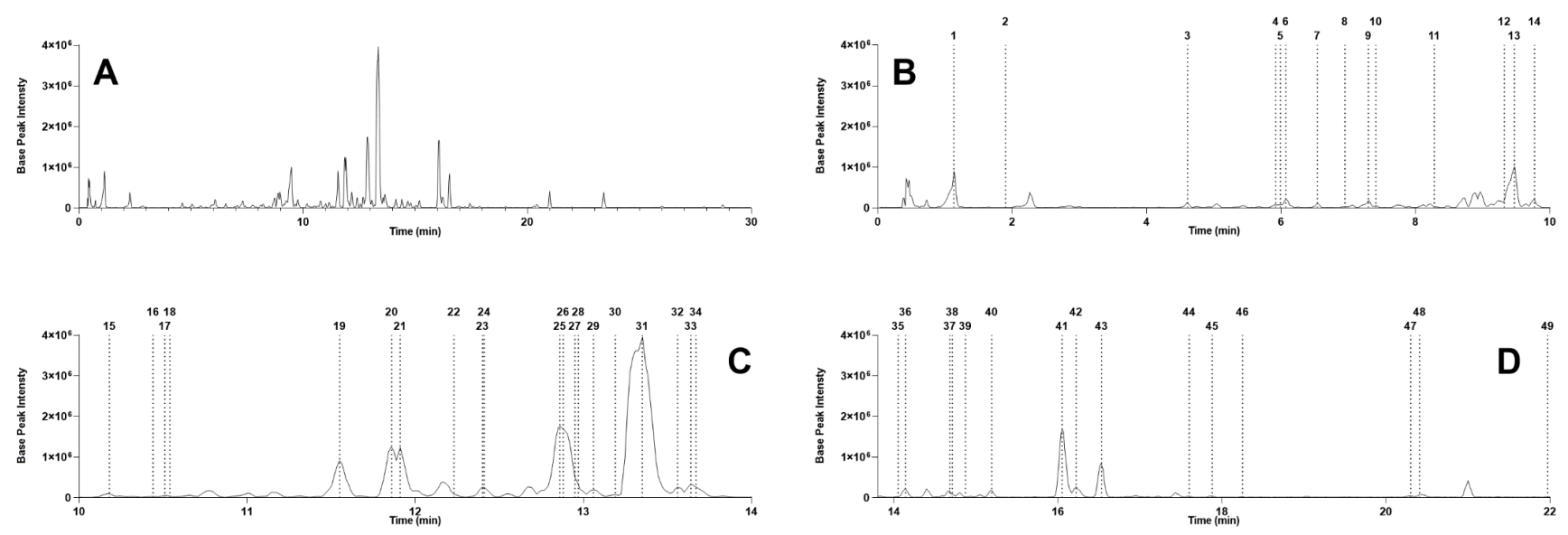

Figure 2. (A) UHPLC-MS/MS total ion chromatograms in the negative ion mode for the leaf extract of Stryphnodendron pulcherrimum. Zoom sections of the chromatograms for (B) 0 to $10 \mathrm{~min},(\mathbf{C}) 10$ to $14 \mathrm{~min}$ and (D) 14 to $22 \mathrm{~min}$. Dashed lines represent the position (retention time) of each dereplicated compound. 
Table 1. UHPLC-MS/MS data of the annotated metabolites in Stryphnodendron pulcherrimum leaf extract.

\begin{tabular}{|c|c|c|c|c|c|c|c|c|c|}
\hline \multirow[b]{2}{*}{ Peak } & \multirow[b]{2}{*}{$\begin{array}{l}\text { RT } \\
(\min )\end{array}$} & \multicolumn{2}{|c|}{$[\mathbf{M}-\mathbf{H}]^{-}$} & \multirow[b]{2}{*}{$\begin{array}{l}\text { Molecular } \\
\text { Formula }\end{array}$} & \multirow[b]{2}{*}{$\begin{array}{l}\text { Error } \\
(\mathrm{ppm})\end{array}$} & \multirow[b]{2}{*}{$\begin{array}{l}\mathrm{MS}^{2} \underset{(\mathrm{m} / z)}{\text { Fragments }} \\
\qquad\end{array}$} & \multirow[b]{2}{*}{ Compound Name } & \multirow[b]{2}{*}{ Spectrum Reference } & \multirow[b]{2}{*}{ Group } \\
\hline & & $\begin{array}{l}\text { Theoretical } \\
\text { Mass }(m / z)\end{array}$ & $\begin{array}{c}\text { Accurate } \\
\text { Mass }(m / z)\end{array}$ & & & & & & \\
\hline 1 & 1.13 & 169.0137 & 169.0138 & $\mathrm{C}_{7} \mathrm{H}_{6} \mathrm{O}_{5}$ & 0.6 & 125 & gallic acid & CCMSLIB00004691622 & 1 \\
\hline 2 & 1.90 & 153.0188 & 153.0191 & $\mathrm{C}_{7} \mathrm{H}_{6} \mathrm{O}_{4}$ & 2.0 & 109 & protocatechuic acid & CCMSLIB00000578339 & 1 \\
\hline 3 & 4.61 & 761.1354 & 761.1332 & $\mathrm{C}_{37} \mathrm{H}_{30} \mathrm{O}_{18}$ & 2.9 & $\begin{array}{l}609,591,573,483 \\
465,453,441,423 \\
355,305,285,177 \\
125\end{array}$ & 3-O-galloyl-(epi)gallocatechin-(epi)gallocatechin & $\mathrm{N} / \mathrm{A}$ & 2 \\
\hline 4 & 5.92 & 305.0661 & 305.0677 & $\mathrm{C}_{15} \mathrm{H}_{14} \mathrm{O}_{7}$ & 5.2 & $261,219,179,125$ & gallocatechin & CCMSLIB00000081482 & 2 \\
\hline 5 & 5.99 & 479.0826 & 479.0837 & $\mathrm{C}_{21} \mathrm{H}_{20} \mathrm{O}_{13}$ & 2.3 & $\begin{array}{c}435,389,313,250 \\
169,125,121\end{array}$ & myricetin 3-sorboside & $\mathrm{N} / \mathrm{A}$ & 3 \\
\hline 6 & 6.07 & 305.0661 & 305.0671 & $\mathrm{C}_{15} \mathrm{H}_{14} \mathrm{O}_{7}$ & 3.3 & $\begin{array}{c}177,150,139,125 \\
109\end{array}$ & (epi)gallocatechin & CCMSLIB00005787972 & 2 \\
\hline 7 & 6.54 & 761.1354 & 761.1348 & $\mathrm{C}_{37} \mathrm{H}_{30} \mathrm{O}_{18}$ & 0.8 & $\begin{array}{c}717,635,609,593 \\
591,575,441,423 \\
405,305,287,243 \\
169,125\end{array}$ & (epi)gallocatechin-3'-O-galloyl-(epi)gallocatechin & $\mathrm{N} / \mathrm{A}$ & 2 \\
\hline 9 & 7.30 & 483.0775 & 483.0786 & $\mathrm{C}_{20} \mathrm{H}_{20} \mathrm{O}_{14}$ & 2.3 & $\begin{array}{l}331,313,287,271 \\
211,169,125\end{array}$ & $\begin{array}{c}\text { [3,4,5-trihydroxy-6-(3,4,5- } \\
\text { trihydroxybenzoyl)oxyoxan-2-yl]methyl } \\
\text { 3,4,5-trihydroxybenzoate Isomer }\end{array}$ & CCMSLIB00000845139 & 1 \\
\hline 10 & 7.41 & 483.0775 & 483.0792 & $\mathrm{C}_{20} \mathrm{H}_{20} \mathrm{O}_{14}$ & 3.5 & $\begin{array}{l}331,313,287,271 \\
211,169,125\end{array}$ & $\begin{array}{c}\text { [3,4,5-trihydroxy-6-(3,4,5- } \\
\text { trihydroxybenzoyl)oxyoxan-2-yl]methyl } \\
\text { 3,4,5-trihydroxybenzoate Isomer }\end{array}$ & CCMSLIB00000845139 & 1 \\
\hline 11 & 8.28 & 483.0775 & 483.0773 & $\mathrm{C}_{20} \mathrm{H}_{20} \mathrm{O}_{14}$ & 0.4 & 169,125 & gallic acid $O$-galloyl glucoside & $\mathrm{N} / \mathrm{A}$ & 1 \\
\hline 12 & 9.32 & 595.1663 & 595.1663 & $\mathrm{C}_{27} \mathrm{H}_{32} \mathrm{O}_{15}$ & 0.0 & $\begin{array}{l}415,385,355,343 \\
325,313,271,235 \\
193,119\end{array}$ & $\begin{array}{l}\text { 3,5,7-trihydroxyflavanone-5-O-[galactopyranosyl- } \\
\text { glucopyranoside] }\end{array}$ & $\mathrm{N} / \mathrm{A}$ & 2 \\
\hline 13 & 9.47 & 457.0771 & 457.0773 & $\mathrm{C}_{22} \mathrm{H}_{18} \mathrm{O}_{11}$ & 0.4 & $\begin{array}{c}305,261,219,179 \\
169,125\end{array}$ & (epi)gallocatechin gallate & CCMSLIB00004702014 & 2 \\
\hline 14 & 9.77 & 467.0826 & 467.0822 & $\mathrm{C}_{20} \mathrm{H}_{20} \mathrm{O}_{13}$ & 0.9 & $\begin{array}{l}449,423,315,313 \\
193,169,152,125 \\
109\end{array}$ & $\begin{array}{c}\text { 3,4,5-trihydroxybenzaldehyde-3-O-[6-O-(3,4,5- } \\
\text { trihydroxybenzoyl)-glucopyranoside] } \\
\text { Isomer }\end{array}$ & $\mathrm{N} / \mathrm{A}$ & 1 \\
\hline 15 & 10.18 & 467.0826 & 467.0835 & $\mathrm{C}_{20} \mathrm{H}_{20} \mathrm{O}_{13}$ & 1.9 & $\begin{array}{l}449,423,315,313 \\
169,152,125,109\end{array}$ & $\begin{array}{c}\text { 3,4,5-trihydroxybenzaldehyde-3-O-[6-O-(3,4,5- } \\
\text { trihydroxybenzoyl)-glucopyranoside] } \\
\text { Isomer }\end{array}$ & $\mathrm{N} / \mathrm{A}$ & 1 \\
\hline
\end{tabular}


Table 1. Cont.

\begin{tabular}{|c|c|c|c|c|c|c|c|c|c|}
\hline \multirow[b]{2}{*}{ Peak } & \multirow[b]{2}{*}{$\begin{array}{c}\text { RT } \\
(\mathrm{min})\end{array}$} & \multicolumn{2}{|c|}{$[\mathbf{M}-\mathbf{H}]^{-}$} & \multirow[b]{2}{*}{$\begin{array}{l}\text { Molecular } \\
\text { Formula }\end{array}$} & \multirow[b]{2}{*}{$\begin{array}{l}\text { Error } \\
(\mathrm{ppm})\end{array}$} & \multirow[b]{2}{*}{$\begin{array}{l}\text { MS }^{2} \text { Fragments } \\
\qquad(\mathrm{m} / \mathrm{z})\end{array}$} & \multirow[b]{2}{*}{ Compound Name } & \multirow[b]{2}{*}{ Spectrum Reference } & \multirow[b]{2}{*}{ Group } \\
\hline & & $\begin{array}{l}\text { Theoretical } \\
\text { Mass }(\mathrm{m} / \mathrm{z})\end{array}$ & $\begin{array}{c}\text { Accurate } \\
\text { Mass }(m / z)\end{array}$ & & & & & & \\
\hline 16 & 10.44 & 465.1033 & 465.1039 & $\mathrm{C}_{21} \mathrm{H}_{22} \mathrm{O}_{12}$ & 1.3 & $\begin{array}{l}447,421,357,313, \\
285,169,151,125 \\
373,316,287,271\end{array}$ & taxifolin- $4^{\prime}$-glucoside & $\mathrm{N} / \mathrm{A}$ & 2 \\
\hline 17 & 10.51 & 625.1405 & 625.1414 & $\mathrm{C}_{27} \mathrm{H}_{30} \mathrm{O}_{17}$ & 1.4 & $\begin{array}{c}259,242,214,178 \\
151,116\end{array}$ & myricetin-3-O-hexosyl-deoxyhexoside & CCMSLIB00004678839 & 3 \\
\hline 18 & 10.54 & 457.0771 & 457.0767 & $\mathrm{C}_{22} \mathrm{H}_{18} \mathrm{O}_{11}$ & 0.9 & $\begin{array}{c}411,383,331,305 \\
169,125\end{array}$ & gallocatechin gallate & CCMSLIB00004702014 & 2 \\
\hline 19 & 11.55 & 479.0826 & 479.0824 & $\mathrm{C}_{21} \mathrm{H}_{20} \mathrm{O}_{13}$ & 0.4 & $\begin{array}{l}316,287,271,259 \\
243,214,151,124\end{array}$ & myricetin 3-galactoside Isomer & CCMSLIB00004706173 & 3 \\
\hline 20 & 11.86 & 479.0826 & 479.0826 & $\mathrm{C}_{21} \mathrm{H}_{20} \mathrm{O}_{13}$ & 0.0 & $\begin{array}{l}316,287,271,259 \\
243,214,151,124\end{array}$ & myricetin 3-galactoside Isomer & CCMSLIB00004706173 & 3 \\
\hline 21 & 11.91 & 477.1033 & 477.1038 & $\mathrm{C}_{22} \mathrm{H}_{22} \mathrm{O}_{12}$ & 1.0 & $\begin{array}{l}316,313,271,169 \\
163,151,125,119\end{array}$ & O-coumaroyl O-galloyl-hexoside & $\mathrm{N} / \mathrm{A}$ & 1 \\
\hline 22 & 12.23 & 761.1354 & 761.1372 & $\mathrm{C}_{37} \mathrm{H}_{30} \mathrm{O}_{18}$ & 2.4 & $\begin{array}{l}609,593,591,575 \\
545,483,465,457 \\
441,423,305,287 \\
243,177,125\end{array}$ & 3-O-galloyl-(epi)gallocatechin-(epi)gallocatechin & $\mathrm{N} / \mathrm{A}$ & 2 \\
\hline 23 & 12.40 & 595.1299 & 595.1306 & $\mathrm{C}_{26} \mathrm{H}_{28} \mathrm{O}_{16}$ & 1.2 & $\begin{array}{l}431,355,316,271 \\
219,179,151,100\end{array}$ & myricetin-3-O-deoxyhexosyl-pentoside & CCMSLIB00004678827 & 3 \\
\hline 24 & 12.41 & 471.0927 & 471.0918 & $\mathrm{C}_{23} \mathrm{H}_{20} \mathrm{O}_{11}$ & 1.9 & $\begin{array}{c}429,347,305,287 \\
183\end{array}$ & 3-O-galloyl-4'-O-methylepigallocatechin & $\mathrm{N} / \mathrm{A}$ & 2 \\
\hline 25 & 12.86 & 495.1503 & 495.1510 & $\mathrm{C}_{23} \mathrm{H}_{28} \mathrm{O}_{12}$ & 1.4 & $\begin{array}{c}313,181,179,169 \\
151,125\end{array}$ & $\begin{array}{c}\text { (3,4,5-trihydroxy-6-(4-(1-hydroxypropan-2-yl)-2- } \\
\text { methoxyphenoxy)tetrahydro-2H-pyran-2- } \\
\text { yl)methyl } \\
\text { 3,4,5-trihydroxybenzoate }\end{array}$ & $\mathrm{N} / \mathrm{A}$ & 1 \\
\hline 26 & 12.88 & 493.1346 & 493.1359 & $\mathrm{C}_{23} \mathrm{H}_{26} \mathrm{O}_{12}$ & 2.6 & $\begin{array}{c}313,181,179,169 \\
151,125\end{array}$ & $\begin{array}{c}\text { (3,4,5-trihydroxy-6-(2-hydroxy-4-(3- } \\
\text { oxobutyl)phenoxy)tetrahydro-2H-pyran-2- } \\
\text { yl)methyl } \\
\text { 3,4,5-trihydroxybenzoate }\end{array}$ & $\mathrm{N} / \mathrm{A}$ & 1 \\
\hline 27 & 12.95 & 477.1033 & 477.1041 & $\mathrm{C}_{22} \mathrm{H}_{22} \mathrm{O}_{12}$ & 1.7 & $\begin{array}{c}433,313,253,241 \\
211,169,163,151 \\
125,119,107\end{array}$ & methoxy-quercetin-3-O-hexoside & CCMSLIB00004678842 & 3 \\
\hline
\end{tabular}


Table 1. Cont.

\begin{tabular}{|c|c|c|c|c|c|c|c|c|c|}
\hline \multirow[b]{2}{*}{ Peak } & \multirow[b]{2}{*}{$\begin{array}{c}\mathrm{RT} \\
(\mathrm{min})\end{array}$} & \multicolumn{2}{|c|}{$[\mathbf{M}-\mathbf{H}]^{-}$} & \multirow[b]{2}{*}{$\begin{array}{l}\text { Molecular } \\
\text { Formula }\end{array}$} & \multirow[b]{2}{*}{$\begin{array}{l}\text { Error } \\
(\mathrm{ppm})\end{array}$} & \multirow[b]{2}{*}{$\begin{array}{l}\mathrm{MS}^{2} \text { Fragments } \\
\qquad(\mathrm{m} / \mathrm{z})\end{array}$} & \multirow[b]{2}{*}{ Compound Name } & \multirow[b]{2}{*}{ Spectrum Reference } & \multirow[b]{2}{*}{ Group } \\
\hline & & $\begin{array}{l}\text { Theoretical } \\
\text { Mass }(m / z)\end{array}$ & $\begin{array}{c}\text { Accurate } \\
\text { Mass }(m / z)\end{array}$ & & & & & & \\
\hline 28 & 12.97 & 609.1456 & 609.1455 & $\mathrm{C}_{27} \mathrm{H}_{30} \mathrm{O}_{16}$ & 0.2 & $\begin{array}{l}495,415,373,300 \\
271,255,243,151 \\
119\end{array}$ & quercetin 3-O-neohesperidoside & CCMSLIB00004679290 & 3 \\
\hline 29 & 13.06 & 449.0720 & 449.0724 & $\mathrm{C}_{20} \mathrm{H}_{18} \mathrm{O}_{12}$ & 0.9 & $\begin{array}{c}359,316,287,210 \\
178,151\end{array}$ & myricetin-3-xyloside Isomer & CCMSLIB00000222475 & 3 \\
\hline 30 & 13.19 & 449.0720 & 449.0727 & $\mathrm{C}_{20} \mathrm{H}_{18} \mathrm{O}_{12}$ & 1.6 & $\begin{array}{c}316,287,271,214 \\
178,151\end{array}$ & myricetin-3-xyloside Isomer & CCMSLIB00000222475 & 3 \\
\hline 31 & 13.35 & 463.0877 & 463.0923 & $\mathrm{C}_{21} \mathrm{H}_{20} \mathrm{O}_{12}$ & 9.9 & $\begin{array}{l}316,287,271,179 \\
151,107\end{array}$ & myricitrin Isomer & CCMSLIB00004718497 & 3 \\
\hline 32 & 13.56 & 479.1553 & 479.1566 & $\mathrm{C}_{23} \mathrm{H}_{28} \mathrm{O}_{11}$ & 2.7 & $\begin{array}{c}313,169,165,151 \\
125,123\end{array}$ & $\begin{array}{l}\text { 3,5-dihydroxy-2-(4-hydroxy-2-isopropyl-5- } \\
\text { methylphenoxy)-6-(hydroxymethyl)tetrahydro- } \\
\text { 2H-pyran-4-yl-3,4,5-trihydroxybenzoate }\end{array}$ & $\mathrm{N} / \mathrm{A}$ & 1 \\
\hline 33 & 13.64 & 615.0986 & 615.0985 & $\mathrm{C}_{28} \mathrm{H}_{24} \mathrm{O}_{16}$ & 0.2 & $463,301,169$ & $\begin{array}{c}{[(2 \mathrm{~S}, 3 \mathrm{R}, 4 \mathrm{~S}, 5 \mathrm{R}, 6 \mathrm{R})-2-[2-(3,4-d i h y d r o x y p h e n y l)-5,7-} \\
\text { dihydroxy-4-oxochromen-3-yl]oxy-4,5-dihydroxy- } \\
\text { 6-(hydroxymethyl)oxan-3-yl] } \\
\text { 3,4,5-trihydroxybenzoate }\end{array}$ & CCMSLIB00004706250 & 3 \\
\hline 35 & 14.05 & 463.0877 & 463.0869 & $\mathrm{C}_{21} \mathrm{H}_{20} \mathrm{O}_{12}$ & 1.7 & $\begin{array}{c}316,300,259,218 \\
179,117\end{array}$ & myricitrin Isomer & CCMSLIB00004706620 & 3 \\
\hline 36 & 14.14 & 463.0877 & 463.0913 & $\mathrm{C}_{21} \mathrm{H}_{20} \mathrm{O}_{12}$ & 7.8 & $\begin{array}{c}300,271,255,179 \\
151,104\end{array}$ & isoquercitrin & CCMSLIB00000077231 & 3 \\
\hline 37 & 14.68 & 433.0771 & 433.0759 & $\mathrm{C}_{20} \mathrm{H}_{18} \mathrm{O}_{11}$ & 2.8 & $\begin{array}{l}387,348,300,249 \\
217,178,113\end{array}$ & avicularin & CCMSLIB00004706151 & 3 \\
\hline 38 & 14.71 & 479.1553 & 479.1549 & $\mathrm{C}_{23} \mathrm{H}_{28} \mathrm{O}_{11}$ & 0.8 & $\begin{array}{l}313,300,169,151 \\
123\end{array}$ & $6^{\prime \prime}$-O-galloylepirhododendrin & $\mathrm{N} / \mathrm{A}$ & 1 \\
\hline 39 & 14.87 & 477.1033 & 477.1037 & $\mathrm{C}_{22} \mathrm{H}_{22} \mathrm{O}_{12}$ & 0.8 & $405,316,300$ & $\begin{array}{l}3^{\prime}, 5,7,8 \text {-tetrahydroxy- } 4^{\prime} \text {-methoxyflavone-8-O- } \\
\text { glucopyranoside }\end{array}$ & $\mathrm{N} / \mathrm{A}$ & 3 \\
\hline 40 & 15.19 & 463.0877 & 463.0906 & $\mathrm{C}_{21} \mathrm{H}_{20} \mathrm{O}_{12}$ & 6.2 & $\begin{array}{l}391,301,272,239 \\
151\end{array}$ & quercetin-4-glucoside & CCMSLIB00004683609 & 3 \\
\hline 41 & 16.05 & 447.0927 & 447.0951 & $\mathrm{C}_{21} \mathrm{H}_{20} \mathrm{O}_{11}$ & 5.3 & $\begin{array}{l}300,271,255,243 \\
151\end{array}$ & quercitrin & CCMSLIB00004679288 & 3 \\
\hline 42 & 16.22 & 317.0297 & 317.0315 & $\mathrm{C}_{15} \mathrm{H}_{10} \mathrm{O}_{8}$ & 5.7 & $178,151,137,107$ & myricetin & CCMSLIB00004705572 & 3 \\
\hline 43 & 16.53 & 479.1553 & 479.1557 & $\mathrm{C}_{23} \mathrm{H}_{28} \mathrm{O}_{11}$ & 0.8 & $169,165,151,125$ & querglanin & $\mathrm{N} / \mathrm{A}$ & 1 \\
\hline
\end{tabular}


Table 1. Cont.

\begin{tabular}{|c|c|c|c|c|c|c|c|c|c|}
\hline \multirow[b]{2}{*}{ Peak } & \multirow[b]{2}{*}{$\begin{array}{c}\mathrm{RT} \\
(\mathrm{min})\end{array}$} & \multicolumn{2}{|c|}{$[\mathbf{M}-\mathbf{H}]^{-}$} & \multirow[b]{2}{*}{$\begin{array}{l}\text { Molecular } \\
\text { Formula }\end{array}$} & \multirow[b]{2}{*}{$\begin{array}{l}\text { Error } \\
(\mathrm{ppm})\end{array}$} & \multirow[b]{2}{*}{$\begin{array}{c}\mathrm{MS}^{2} \text { Fragments } \\
(\mathrm{m} / \mathrm{z})\end{array}$} & \multirow[b]{2}{*}{ Compound Name } & \multirow[b]{2}{*}{ Spectrum Reference } & \multirow[b]{2}{*}{ Group } \\
\hline & & $\begin{array}{l}\text { Theoretical } \\
\text { Mass }(\mathrm{m} / \mathrm{z})\end{array}$ & $\begin{array}{c}\text { Accurate } \\
\text { Mass }(m / z)\end{array}$ & & & & & & \\
\hline 44 & 17.60 & 433.1135 & 433.1137 & $\mathrm{C}_{21} \mathrm{H}_{22} \mathrm{O}_{10}$ & 0.5 & $\begin{array}{c}313,169,151,125 \\
119\end{array}$ & phlorizin chalcone & $\mathrm{N} / \mathrm{A}$ & 1 \\
\hline 45 & 17.88 & 447.0927 & 447.0936 & $\mathrm{C}_{21} \mathrm{H}_{20} \mathrm{O}_{11}$ & 2.0 & $\begin{array}{c}432,405,285,199,1 \\
75,151,113\end{array}$ & luteolin-4'-O-glucoside & CCMSLIB00004720065 & 3 \\
\hline 46 & 18.25 & 431.0978 & 431.0956 & $\mathrm{C}_{21} \mathrm{H}_{20} \mathrm{O}_{10}$ & 5.1 & $\begin{array}{c}314,285,255,227 \\
124\end{array}$ & kaempferol-7-O-deoxyhexoside & CCMSLIB00004678854 & 3 \\
\hline 47 & 20.30 & 301.0348 & 301.0354 & $\mathrm{C}_{15} \mathrm{H}_{10} \mathrm{O}_{7}$ & 2.0 & $257,178,145,116$ & tricetin & CCMSLIB00004691766 & 3 \\
\hline 48 & 20.41 & 285.0399 & 285.0404 & $\mathrm{C}_{15} \mathrm{H}_{10} \mathrm{O}_{6}$ & 1.7 & 251, 183, 116 & $3^{\prime}, 4^{\prime}, 5,7$-tetrahydroxyflavone & CCMSLIB00004691238 & 3 \\
\hline 49 & 21.97 & 315.0505 & 315.0506 & $\mathrm{C}_{16} \mathrm{H}_{12} \mathrm{O}_{7}$ & 0.3 & $300,231,188,116$ & 3'-O-methylquercetin & CCMSLIB00000081595 & 3 \\
\hline
\end{tabular}

Note: 1: gallic acid group; 2: flavan-3-ols group; 3: flavones group. N/A: not available, meaning this annotation is a spectral match against the in silico database. 


\subsection{Structural Identification of Compounds Present in the Extract of S. pulcherrimum}

According to our annotation results, 30 out 49 compounds had a spectral match against the experimental database from GNPS, while the remaining 19 had a match against the in silico database. To corroborate the structural proposals for these 19 features, their individual fragmentation patterns were explained. Figure 3 display examples of fragmentation patterns for each structural group. Group 1 includes conjugates of gallic acid with sugars and small organic acids (Figure 4). Fragmentation patterns of these compounds are characterized by the ions of $m / z 169$ (gallate) and 125 (3,4,5-trihydroxybenzene, ion derived from the decarboxylation of the gallate) [50,51]. If a sugar unit is present, common losses of $\mathrm{H}_{2} \mathrm{O}$ and consecutive losses of $\mathrm{C}_{2} \mathrm{H}_{4} \mathrm{O}_{2}$ units from the residual hexose and the heterolytic cleavage of the sugar are observed [52]. For Group 2 (flavan-3-ol derivatives, Figure 5), the most characteristic fragmentation includes quinone methide fission (QM), heterolytic ring fission (HRF) and retro-Diels-Alder (RDA) cleavage, which inform the hydroxylation patterns in the different rings $(\mathrm{A}, \mathrm{B}$ and $\mathrm{C})[53,54]$ and the identity of the monomeric units. Group 3 is mainly composed of glycosylated flavones (Figure 6). Their fragmentation usually yields a fragment ion of $m / z 316\left[\mathrm{C}_{15} \mathrm{H}_{9} \mathrm{O}_{8}{ }^{\bullet}-\mathrm{H}\right]^{\bullet-}$, which points to homolytic cleavage and loss of the glycoside radical (sugar unit) $[55,56]$. Fragment ions of $m / z 301$ and 300 are both indicative of heterocyclic or homolytic cleavage and loss of the glycoside [56]. The fragment ion [(Aglycone- $\left.-\mathrm{H})-\mathrm{CO}_{2}\right]^{-}$of $m / z 271$ is also usually formed. The relatively light fragment ion of $m / z 151$ is produced by RDA cleavage of the aglycone [54,57].

The gallic acid derivative group, contributing to the main part of the cluster of Figure 4, covers a wide range of polarities (RT from 1 to $17 \mathrm{~min}$, Figure 2). For example, 8 was putatively assigned to 6-O-galloylarbutin. Its fragment ion of $m / z 313$ is likely produced by loss of dihydroxybenzene $\left[\mathrm{M}-\mathrm{H}-\mathrm{C}_{6} \mathrm{H}_{6} \mathrm{O}_{2}\right]^{-}$, whereas that of $m / z 253$ is likely from loss of the gallate moiety $\left[\mathrm{M}-\mathrm{H}-\mathrm{C}_{7} \mathrm{H}_{6} \mathrm{O}_{5}\right]^{-}$. The fragments ions of $m / z 169$ and 125 seem to be formed after a gallate loss followed by consecutive losses of $\mathrm{CO}_{2}$. As another example, $\mathbf{1 1}$ was assigned as gallic acid $\mathrm{O}$-galloyl glucoside, an isomer of $\mathbf{9}$ and 10. For this isomer, we proposed that the $\mathrm{C}-\mathrm{O}-\mathrm{C}$ bridge between the hexose and a gallic acid moiety is linked at $\mathrm{C} 4$ of the benzoate. In such connectivity, this bond is weaker, which could explain the variation in abundance of fragment ions with respect to 9 and 10. The fragment ion of $m / z$ $169\left[\mathrm{M}-\mathrm{H}-\mathrm{C}_{13} \mathrm{H}_{16} \mathrm{O}_{9}\right]^{-}$is the base peak, suggesting cleavage of the $\mathrm{C}-\mathrm{O}$ bond $(\mathrm{C} 2$ in the hexose) and loss of the hexose and gallate groups as neutral species. $\mathrm{CO}_{2}$ loss likely forms the fragment ion of $m / z 125\left[\mathrm{M}-\mathrm{H}-\mathrm{C}_{13} \mathrm{H}_{16} \mathrm{O}_{9} \mathrm{CO}_{2}\right]^{-}$.

We identified 10 compounds, as illustrated in Figure 5, in the flavan-3-ols category, presenting a 2-phenyl-3,4-dihydro-2H-chromen-3-yl backbone [58]. These types of compounds are commonly used as functional/nutritional agents for beverages, fruits and vegetables, food grains, herbal remedies, dietary supplements and dairy products [59], or as ligand for protein inactivation, which prevent the growth of microorganisms [31]. 

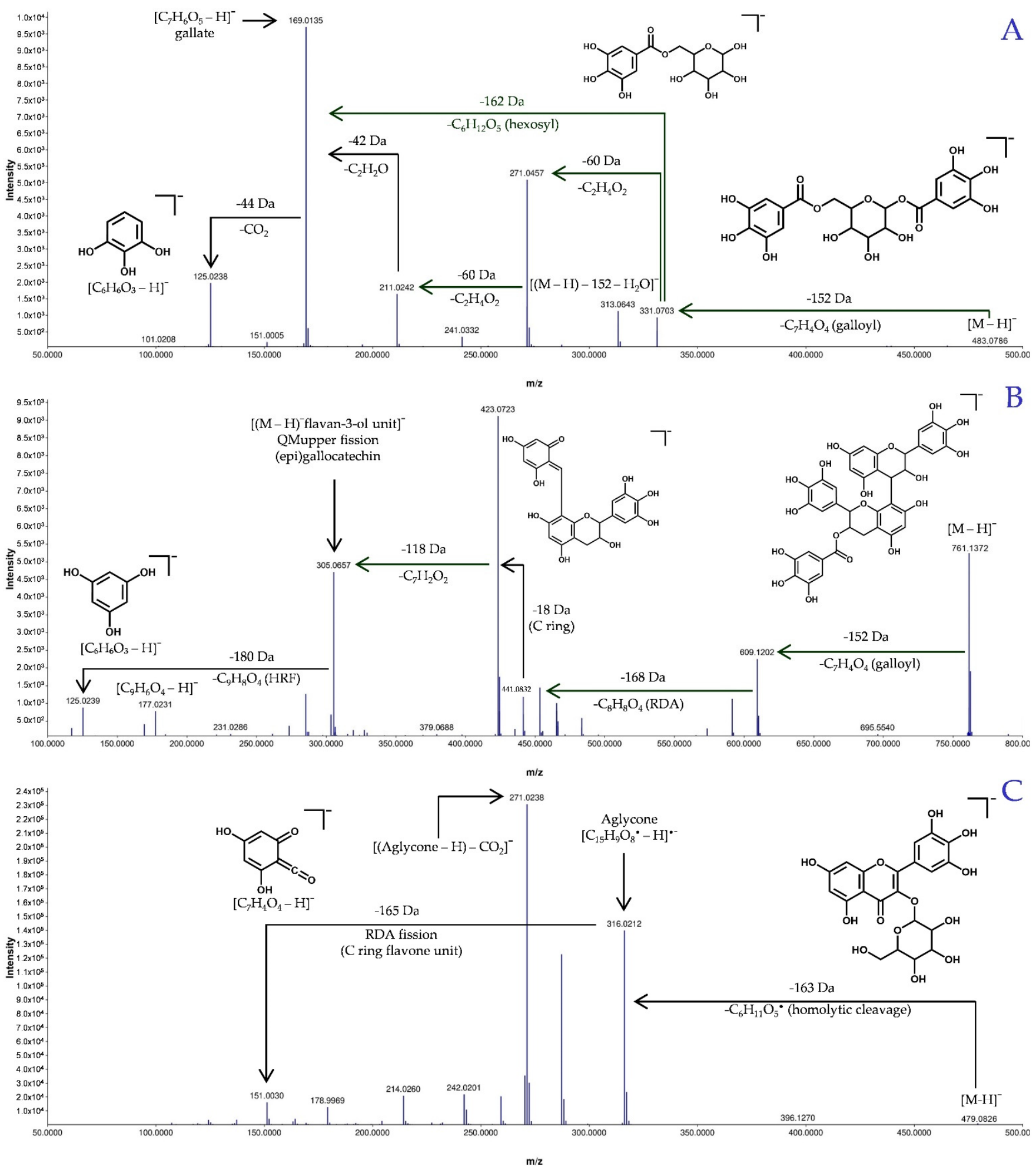

Figure 3. MS/MS for representative $[\mathrm{M}-\mathrm{H}]^{-}$molecular ions from each group. Group 1 (A), [3,4,5-trihydroxy-6-(3,4,5trihydroxybenzoyl)oxyoxan-2-yl]methyl-3,4,5-trihydroxybenzoate (9), gallic acid derivatives; Group 2 (B), 3-O-galloyl(epi)gallocatechin-(epi)gallocatechin (22), flavan-3-ol derivatives; and Group 3 (C), myricetin-3-galactoside (20), flavone derivatives. 


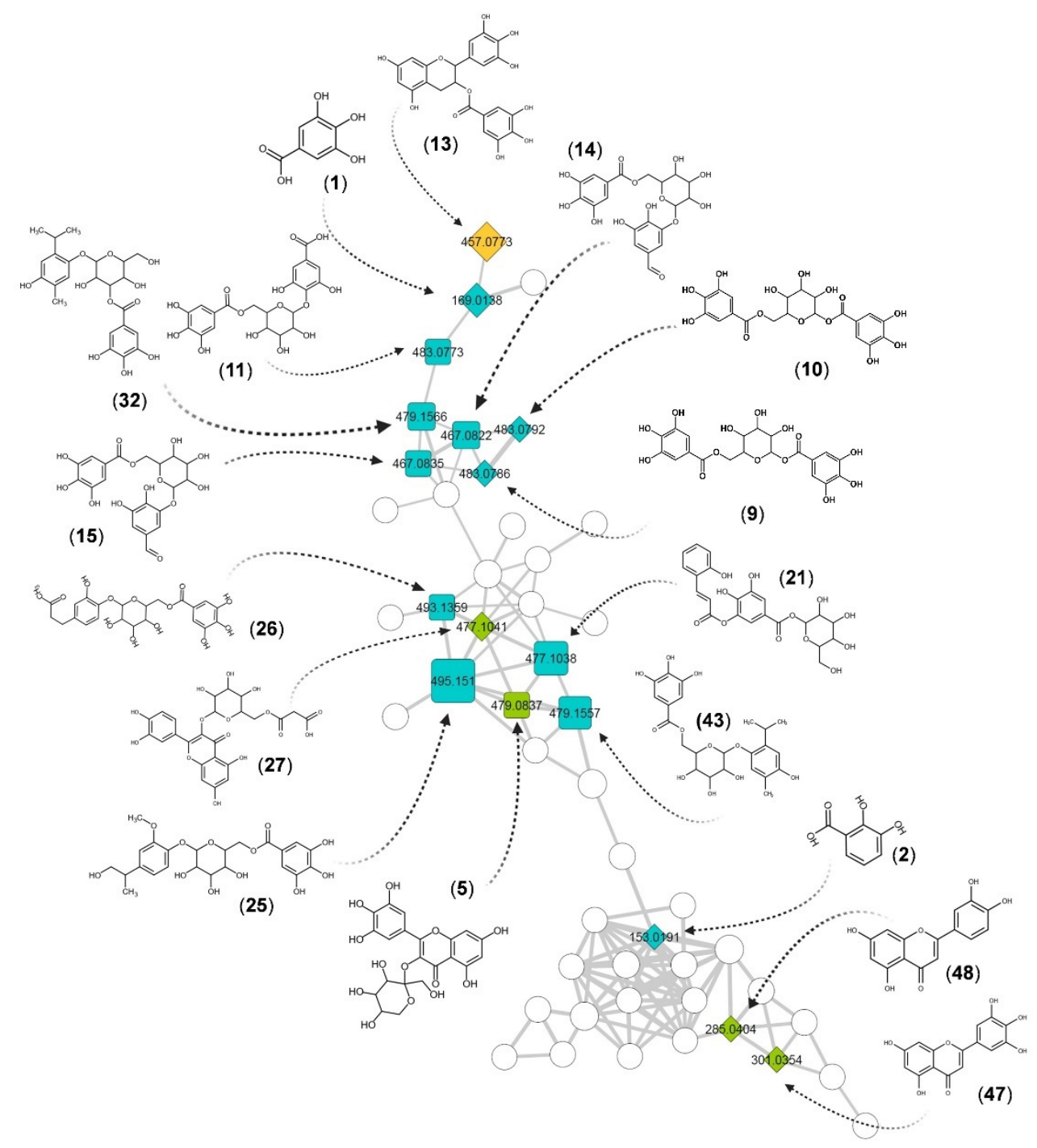

Figure 4. Gallic acid derivatives in the largest cluster of the network. Numbers inside the nodes correspond to the accurate mass for each precursor. Node size is proportional to the intensity of the ions in the total ion chromatogram. Node colors represent structural groups: gallic acid derivatives (G1, blue), flavan-3-ol derivatives (G2, orange) and flavone derivatives (G3, green). Rhomboid shapes correspond to a match against an experimental $\mathrm{MS}^{2}$; square shapes are identifications from in silico spectra matching. 


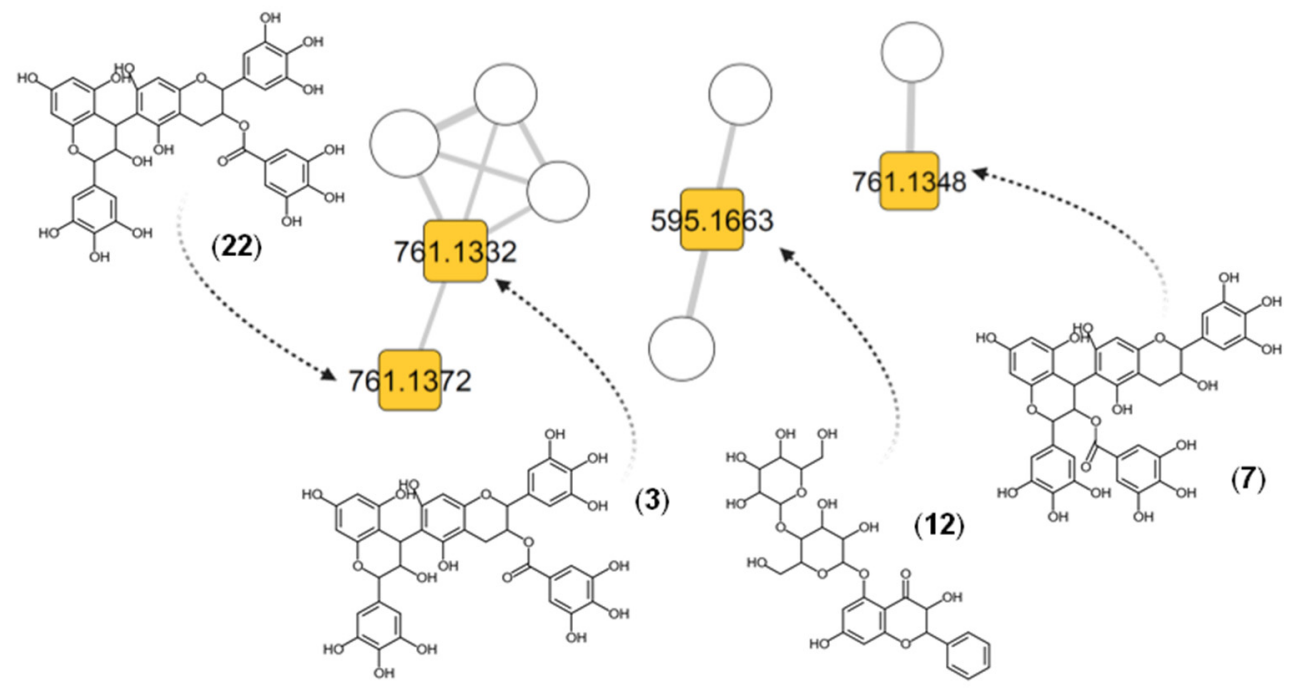

Figure 5. Illustrative compounds assigned as flavan-3-ol derivatives (Group 2). Numbers inside the nodes correspond to the accurate mass for each precursor. Node size is proportional to the intensity of the ion peaks in the total ion chromatograms. Node colors represent the three different groups: gallic acid derivatives (G1, blue), flavan-3-ol derivatives (G2, orange) and flavone derivatives (G3, green). Rhomboid shapes correspond to a match against an experimental MS² ; square shapes are identifications from in silico spectra matching.

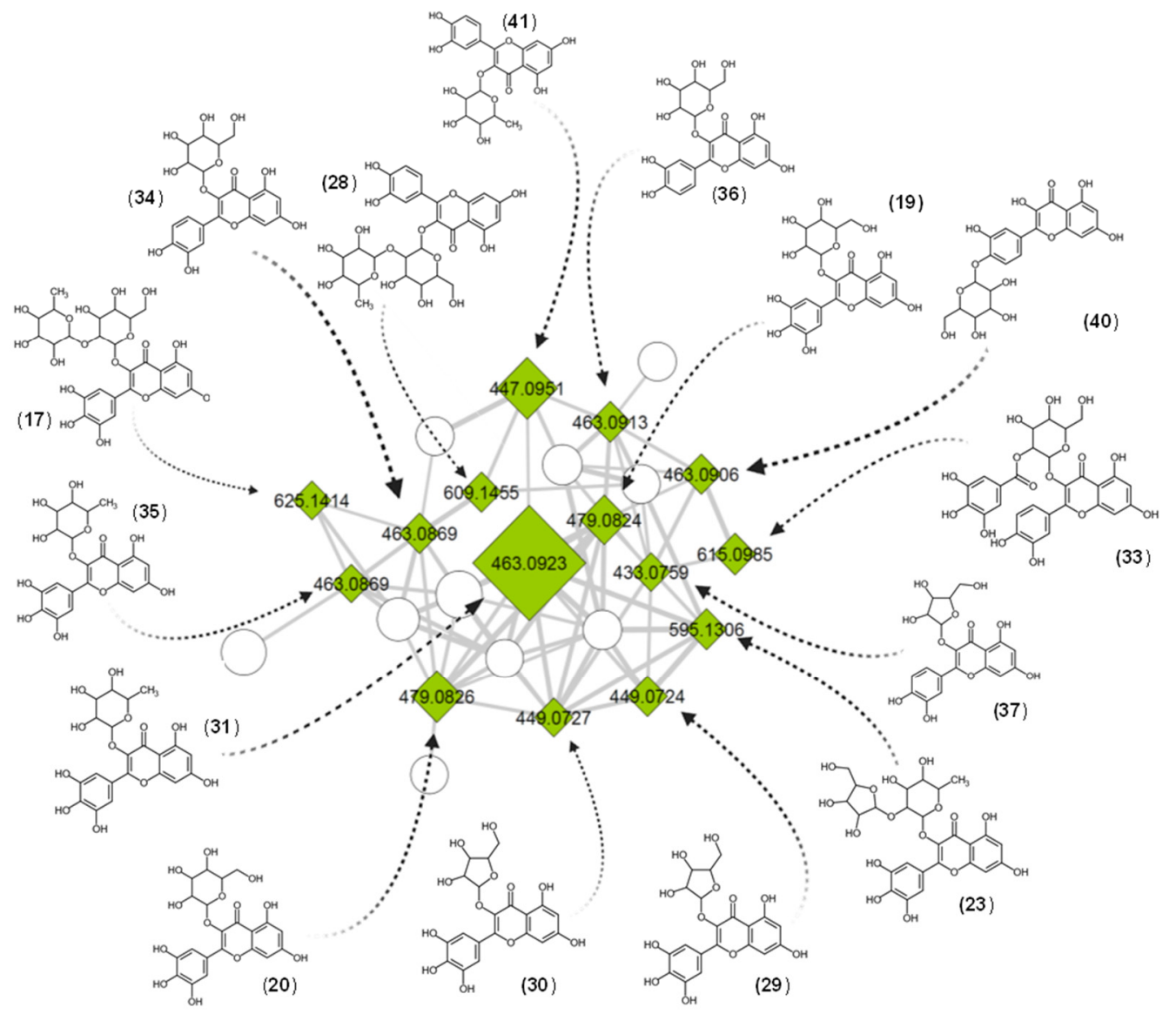

Figure 6. Compounds assigned mainly as flavone derivatives in the cluster belonging to Group 3. Numbers inside the nodes correspond to the accurate mass for each precursor. Node size is proportional to the intensity of the ions in the total ion chromatogram. Node colors represent the three different groups: gallic acid derivatives (G1, blue), flavan-3-ol derivatives (G2, orange) and flavone derivatives (G3, green). Rhomboid shapes correspond to a match against an experimental MS² square shapes are identifications from in silico spectra matching. 
For example, three $\mathrm{C}_{37} \mathrm{H}_{30} \mathrm{O}_{18}$ isomers: $[\mathrm{M}-\mathrm{H}]^{-}$of $m / z 761.1332(3,4.61 \mathrm{~min}), 761.1348$ (7, $6.54 \mathrm{~min})$ and $761.1372(22,12.23 \mathrm{~min})$ were assigned as (epi)gallocatechin dimmer conjugates: 3-O-galloyl-(epi)gallocatechin-(epi)gallocatechin (3), (epi)gallocatechin-3'-Ogalloyl-(epi)gallocatechin (7) and 3-O-galloyl-(epi)gallocatechin-(epi)gallocatechin. The $\mathrm{MS}^{2}$ of 22 is illustrated in Figure 3B. These three isomeric $[\mathrm{M}-\mathrm{H}]^{-}$yielded common fragment ions such as $m / z 609$ for the loss of the gallate group $\left[\mathrm{M}-\mathrm{H}-\mathrm{C}_{7} \mathrm{H}_{4} \mathrm{O}_{4}\right]^{-}, m / z$ 591 for the loss of $\mathrm{H}_{2} \mathrm{O}$ from the $\mathrm{C}$ ring $\left[\mathrm{M}-\mathrm{H}-\mathrm{C}_{7} \mathrm{H}_{4} \mathrm{O}_{4}-\mathrm{H}_{2} \mathrm{O}\right]^{-}$), $m / z 441$ for RDA [M-H$\left.\mathrm{C}_{7} \mathrm{H}_{4} \mathrm{O}_{4}-\mathrm{C}_{8} \mathrm{H}_{8} \mathrm{O}_{4}\right]^{-}, m / z 423$ for the loss of $\left.\mathrm{H}_{2} \mathrm{O}\left[\mathrm{M}-\mathrm{H}-\mathrm{C}_{7} \mathrm{H}_{4} \mathrm{O}_{4}-\mathrm{C}_{8} \mathrm{H}_{8} \mathrm{O}_{4}-\mathrm{H}_{2} \mathrm{O}\right]^{-}\right), m / z$ 305 from the loss of a monomeric unit (quinone methide reaction [60]) and $\mathrm{m} / \mathrm{z} 125$ from further loss of a $\mathrm{C}_{9} \mathrm{H}_{8} \mathrm{O}_{4}$ unit. Fragment ions of $m / z 593$ and 575 (7 and 22) likely result from further consecutive losses of $\mathrm{H}_{2} \mathrm{O}\left[\mathrm{M}-\mathrm{H}-\mathrm{C}_{7} \mathrm{H}_{4} \mathrm{O}_{4}-2 \mathrm{H}_{2} \mathrm{O}\right]^{-}$. The fragment ion of $m / z 405$ likely results from RDA followed by double $\mathrm{H}_{2} \mathrm{O}$ losses $\left[\mathrm{M}-\mathrm{H}-\mathrm{C}_{8} \mathrm{H}_{8} \mathrm{O}_{4}-2 \mathrm{H}_{2} \mathrm{O}\right]^{-}$. The ion of $m / z 287$ [M-H-QM- $\left.\mathrm{H}_{2} \mathrm{O}\right]^{-}$likely results from the monomeric unit of $m / z$ 305. Further HRF reactions seem to produce the ion of $m / z 243\left[\mathrm{M}-\mathrm{H}-\mathrm{QM}-\mathrm{C}_{2} \mathrm{H}_{6} \mathrm{O}_{2}\right]^{-}$, and the ion of $m / z 169$ seems to correspond to the gallate anion. Compounds 3 and 22 showed additional fragment ions of $m / z$ 483, 465 and 177. For [M- $\left.\mathrm{H}-\mathrm{C}_{7} \mathrm{H}_{4} \mathrm{O}_{4}-\mathrm{C}_{6} \mathrm{H}_{6} \mathrm{O}_{3}\right]^{-}$ of $m / z 483$, loss of 1,3,5-trihydroxybenzene seems likely, followed by $\mathrm{H}_{2} \mathrm{O}$ loss [M-H$\left.\mathrm{C}_{7} \mathrm{H}_{4} \mathrm{O}_{4}-\mathrm{C}_{6} \mathrm{H}_{6} \mathrm{O}_{3} \mathrm{H}_{2} \mathrm{O}\right]^{-}$to yield the ion of $m / z 465$. The fragment ion of $m / z 177$ has been reported [60] and seems to result from the ion of $m / z 305$ by $\mathrm{C}_{6} \mathrm{H}_{8} \mathrm{O}_{3}$ loss, but the corresponding pathway is still unknown. However, 3 showed unique fragment ions of $m / z$ $573,453,355$ and 285. That of $m / z 573$ seems to result from $m / z 591$ by $\mathrm{H}_{2} \mathrm{O}$ loss [M-H$\mathrm{C}_{7} \mathrm{H}_{4} \mathrm{O}_{4}-2 \mathrm{H}_{2} \mathrm{O}^{-}$, whereas subsequent $\mathrm{C}_{7} \mathrm{H}_{4} \mathrm{O}_{2}$ loss yields $m / z 453$. The ion of $m / z 355$ has a $\left[\mathrm{M}-\mathrm{H}-338-\mathrm{C}_{3} \mathrm{O}_{2}\right]^{-}$composition and likely results from that of $m / z 423$ [61]. Compound 7 yielded fragment ions of $m / z 717\left[\mathrm{M}-\mathrm{H}-\mathrm{CO}_{2}\right]^{-}$and $m / z 635\left[\mathrm{M}-\mathrm{H}-\mathrm{C}_{6} \mathrm{H}_{6} \mathrm{O}_{2}\right]^{-}$, both corresponding to trihydroxybenzene loss from [M-H] $]^{-}$of $m / z 761$. We suggest that these ions point to the galloyl group position of this compound at C-3 on the extension unit of the flavone. Unlike compounds 3 and 22, which differ in position (C-3 in the base unit of the flavone), probably conferring the weakest stability bond.

For the last group of chemical structures, a total of 24 flavone derivatives were detected and annotated (Figure 6). Flavones have a double bond between C2 and C3 (C ring) in the flavonoid structure and they are oxidized at $\mathrm{C} 4$ and are reported to have a variety of biological activities [62,63].

Compound 5 was assigned to myricetin 3-sorboside, based on its fragmentation pattern. From dereplication on ISDB, we suggest that its $\mathrm{CH}_{2} \mathrm{OH}$ group is not at the C-5 position of the hexose, as in myricetin 3-galactoside, but at C-1. This assignment is justified by the uncommon fragment ions of $m / z 250$ and 121. This structural difference may explain why 5 clustered with the gallic acid derivatives (Figure 1 and Figure S1). Compound 39 was assigned from ISDB data yielding fragment ions of $m / z 405\left(\left[\mathrm{M}-\mathrm{H}-\mathrm{C}_{3} \mathrm{H}_{4} \mathrm{O}_{2}\right]^{-}\right.$from ${ }^{3,5} \mathrm{X}_{1}$ fragmentation on a glucopyranoside, $m / z 316$ from loss of a glucopyranoside [M$\left.\mathrm{C}_{6} \mathrm{H}_{10} \mathrm{O}_{5}\right]^{-\bullet}$ ) and $m / z 300$ from $\mathrm{CH}_{3} \bullet$ loss $\left[\mathrm{M}-\mathrm{C}_{6} \mathrm{H}_{10} \mathrm{O}_{5}-\mathrm{CH}_{3}\right]^{-\bullet}$, as 3',5,7,8-tetrahydroxy$4^{\prime}$-methoxyflavone-8-O-glucopyranoside. For more detailed descriptions of the remaining dereplicated ions, refer to the Supplementary information. The fragmentation pathways for the major compounds (13, 21, 25, 31 and 41) are presented in Figures S4-S8.

\section{Discussion}

Several Stryphnodendron species have been the focus of chemical studies to identify their chemical composition, and to assess the natural products responsible for the reported biological activities, such as anti-inflammatory and antimicrobial [3,14-29]. The many uses of these plants in Brazilian folk medicine point to them as possible sources of bioactive compounds $[30,31]$.

In this study, we aimed to comprehensively describe the composition of the leaves Stryphnodendron pulcherrimum based on the annotation of all metabolites detected in the hydro-acetonic extract by UHPLC-MS/MS. The combination of spectral organization through $\mathrm{MN}$ [34] and the search against both experimental and in silico spectral databases 
considerably reduces the time and resources for the putative identification of a considerable number of metabolites. Combining the MN with matching of MS/MS against in silico databases [35] was possible re-weighting of the putative candidates based on the biological source and taxonomy [36]. Also, filtering with MF assignment and manually verifying major fragmentation patterns allowed us to significantly increase the confidence of the metabolite annotation.

All compounds reported here, mainly small phenolic conjugates and polyphenols, derive either from the upper stream of the shikimate, phenylpropanoid or phenylpropanoidacetate pathway. The MN presents two major clusters. The largest one is mainly constituted by compounds from G1 (Figure 4) which are derivatives and conjugates of gallic acid (1). Note that gallic acid displays several biological activities and is considered a biomarker for the chemotaxonomy and differentiation of Stryphnodendron species because of its recurrence and concentration [43,64-67].

The second G3 major cluster, composed entirely of flavone derivatives (Figure 6), contains the most abundant compounds according to their ion intensities in the TIC trace (Figure 2). Myricitrin (31) displays a wide range of biological activities and is remarkable as an anti-inflammatory and antioxidant agent [68-73]. Additionally, a smaller group of compounds bearing a flavan-3-ol core structure was putatively identified. We unequivocally detected and identified gallocatechin and (epi)gallocatechin $(4,6)$. These, along with catechin and other monomeric units, are the precursors of most condensed tannins $[59,74]$. The added value of this type of study lies in previous findings in which some of the identified compounds have been reported in other biological sources as promising bioactive agents for the pharmaceutical industry.

Some examples of these well-characterized compounds include (epi)gallocatechin gallate (13), coumaroyl-O-galloyl-glucose (21), (3,4,5-trihydroxy-6-(4-(1-hydroxypropan-2yl)-2-methoxyphenoxy)tetrahydro-2H-pyran-2-yl)methyl-3,4,5-trihydroxybenzoate (25), myricitrin (31) and quercitrin (41), which are the major compounds in the studied extract of S. pucherrimum. (Epi)gallocatechin gallate (13) and its analogues have been reported as proteasome inhibitors [75], preventers of degenerative brain diseases [76], antibacterial [77], antiviral, antifungal [78], part of cancer treatments [79,80] and modulators of cyclooxygenase-2, oxidative stress and inflammation of different cellular processes [80]. Coumaroyl-O-galloyl-glucose (21) has been reported in extracts with wound healing properties [81] and antioxidant, anti-inflammatory, antimutagenic, antimicrobial [82] and antidiarrheal activities [83]. Similarly, (3,4,5-trihydroxy-6-(4-(1-hydroxypropan-2-yl)-2methoxyphenoxy)tetrahydro-2H-pyran-2-yl)methyl-3,4,5-trihydroxybenzoate (25) is a natural product present in traditional Chinese medicine [84].

Myricitrin (31) was the most intensity compound found in the extract. It was recently proposed to pre-treat liver ischemia/reperfusion injury [69], and it also presents antithrombotic [70], osteoarthritis [71], antioxidant, anti-inflammatory and antifibrotic [72] activities. Quercitrin (41) was recently described to reduce the infarct volume in stroke in mouses [85], to display inflammatory [86], antiproliferative and anti-apoptotic effects on lung cancer cells [87] and to have cytoprotective effects against free radicals [88].

The metabolites present in the leaves of S. pulcherrimum have therefore great biological potential, some of them already proven, and some yet to be discovered, making this plant a promising new, natural and renewable Amazonian source of bioactive molecules. The dereplication process employed proved to be efficient, producing valuable information about the chemical composition in a considerably reduced time compared to classical phytochemical studies. Finally, the description of the various structurally new secondary metabolites.

\section{Materials and Methods}

4.1. Chemicals and Reagents

Sodium hypochlorite p.a. was acquired from Dinâmica (Jaraguá do Sul, SC, Brazil). Ethyl alcohol (99\%) was acquired from Êxodo científica (Sumaré, SP, Brazil). Acetone 
chromatographic grade and methanol LC-MS grade were acquired from Tedia (Fairfield, $\mathrm{OH}, \mathrm{USA}$ ). Formic acid was purchased from Merck (Darmstadt, Germany). Ultrapure water was produced by a Direct-Q 5 system (Millipore, Merck Darmstadt, Germany).

\subsection{Plant Material Collection and Extraction}

Stryphnodendron pulcherrimum leaves were collected in September 2019 in Vigia (PA, Brazil). It is associated with the research project registered in SISGEN under number A678D8C. An exsiccate (Voucher IAN 199608) was deposited in the herbarium of Embrapa Amazônia Oriental, Pará, Brazil. The leaves were washed with water and then disinfected with a sodium hypochlorite solution $(\mathrm{NaOCl}, 0.1 \%)$, followed by ethyl alcohol $(70 \% v / v)$. Then, the leaves were dried in an air circulation oven at $45^{\circ} \mathrm{C}$ until constant weight. The dried leaves were crushed in a Fritsch pulverisette 14 ball mill (Idar-Oberstein, RP, Germany.), obtaining $1.866 \mathrm{~kg}$ of powder with a $60-100 \mu \mathrm{m}$ particle size.

A total of $20 \mathrm{~g}$ of powder was extracted with $100 \mathrm{~mL}$ of $\mathrm{H}_{2} \mathrm{O} /$ Acetone (3:7) in an ultrasound bath, Branson 2510 (Danbury, CT, USA), for 40 min at $25^{\circ} \mathrm{C}$ as previously reported [28]. The liquid was vacuum filtered, and the solvent was reduced under vacuum in a rotary evaporator Büchi Syncore (Flawil, Switzerland). A total of $6 \mathrm{~g}$ of dry extract (HCOE) was obtained. The extract was kept at $-18^{\circ} \mathrm{C}$ in a freeze Indrel (Londrina, PR, Brazil) until analysis.

\subsection{Sample Preparation for UHPLC-MS/MS}

HCOE (1 mg) was solubilized in $1 \mathrm{~mL}$ of $\mathrm{H}_{2} \mathrm{O} /$ Methanol (2:8 $\left.v / v\right)$ and passed through a $50 \mathrm{mg}$ C18 Solid Phase Extraction (SPE, Phenomenex, Torrance, CA, USA) cartridge, previously conditioned with $1 \mathrm{~mL}$ of methanol and $1 \mathrm{~mL}$ of water. The filtrate was dried, and the solid residue was dissolved in $1 \mathrm{~mL}$ of methanol, filtered through a $0.22 \mu \mathrm{m}$ hydrophilic filter (Millipore, Merk, Darmstadt, Germany) and diluted to $100 \mu \mathrm{g} / \mathrm{mL}$.

\subsection{UHPLC-MS/MS}

The analyses were performed on a UHPLC coupled to an ESI-QTof Xevo G2-S Tof mass spectrometer (Waters Corp., Milford, MA, USA) with an electrospray ionization (ESI) probe operating in the negative ion mode. The $m / z$ mass was 100-1200, and Leucine-enkephalin was used as a LockSpray reference compound. Analysis by UHPLC was carried out on a BEH C18 $(50 \times 2.1 \mathrm{~mm}, 1.7 \mu \mathrm{m})$ Waters column. The column and autosampler were kept at 40 and $25^{\circ} \mathrm{C}$, respectively. Elution was performed with ultra-pure water (solvent A) and methanol acidified with $0.1 \%$ formic acid (solvent $\mathrm{B}$ ). The gradient method was set as follows: $0-2 \mathrm{~min}, 2 \%$ B $2-10 \mathrm{~min}, 2-10 \%$ B; $10-20 \mathrm{~min}, 10-20 \%$ B; $20-25 \mathrm{~min}, 20-30 \%$ B; $25-30 \mathrm{~min}, 30-40 \% \mathrm{~B}$. The flow rate was $250 \mu \mathrm{L} / \mathrm{min}$. The total ion chromatogram was acquired using Masslynx V4.1 software (Waters Corp., Milford, MA, USA). The mass spectrometry parameters were set to the following: desolvation gas flow $\left(\mathrm{N}_{2}\right)$ at $600 \mathrm{~L} / \mathrm{h}$ and desolvation temperature at $150{ }^{\circ} \mathrm{C}$, the cone gas flow $\left(\mathrm{N}_{2}\right)$ at $50 \mathrm{~L} / \mathrm{h}$ and the source temperature at $120^{\circ} \mathrm{C}$. The capillary and sampling cone voltages were adjusted to $1.0 \mathrm{kV}$ and $40 \mathrm{~V}$, respectively.

The data-dependent experiments (DDA, MS/MS) were performed on the five most abundant ions detected in full-scan MS (top 5 experiments per scan). The ion peaks were detected at +1 and +2 charge states with the inclusion of the 10 most intense ion peaks with $0.2 \mathrm{Da}(\mathrm{m} / \mathrm{z})$ charge state tolerance and $2 \mathrm{Da}$ extraction tolerance. The differentiation of molecular ions, adducts and fragment ions was conducted by chromatographic deconvolution with 3 Da de-isotope tolerance and 6 de-isotope extraction tolerance. The MS/MS isolation window width was $1 \mathrm{Da}$, and the stepped normalized collision energy (NCE) was set to $10,20,30,40$ and $50 \mathrm{eV}$ units.

\subsection{Mass Spectrometry Data Treatment Parameters}

The UHPLC-MS/MS data were converted from RAW (Waters Corp., Milford, MA, USA) standard data format to mzXML format using MSConvert 3.0.2 [89]. The resulting 
file was treated using MZmine v2.53 [33]. For mass detection, at $\mathrm{MS}^{1}$ and $\mathrm{MS}^{2}$ levels, noise levels of $5.0 \mathrm{E}^{2}$ and $0.0 \mathrm{E} 0$ were used. The ADAP chromatogram builder algorithm was used and set to a minimum group size of scans of 3, minimum group intensity threshold of $5.0 \mathrm{E}^{2}$ and minimum highest intensity of $5.0 \mathrm{E}^{2}$ with an $m / z$ tolerance of $12.0 \mathrm{ppm}$. The ADAP algorithm (wavelets) was used for chromatogram deconvolution. The intensity window $\mathrm{S} / \mathrm{N}$ was used as $\mathrm{S} / \mathrm{N}$ estimator with a signal to noise ratio set to 5 , a minimum feature height of $5.0 \mathrm{E}^{2}$, a coefficient area threshold of 50 , a peak duration range from 0.01 to $1.0 \mathrm{~min}$ and an RT wavelet range from 0.01 to $0.08 \mathrm{~min}$. Isotopes were detected using the isotope peak grouper with an $\mathrm{m} / \mathrm{z}$ tolerance of $5.0 \mathrm{ppm}$, an RT tolerance of $0.05 \mathrm{~min}$ (absolute) and the maximum charge set at 1 and the representative isotope used was the most intense. The resulting peak list was filtered using the peak-filter option (height: $1.0 \mathrm{E}^{4}$ to $1.0 \mathrm{E}^{7}$, data points: 8 to 50 , tailing factor: 0.5 to 2.00 ). Last, using the peak-list rows filter option, features without an $\mathrm{MS}^{2}$ spectrum associated were removed. The resulting peak list, containing 283 features, was exported using the GNPS Export/Submit module to an .mgf file and a quantitation table in csv format.

\subsection{Feature-Based Molecular Networking and Taxonomically Informed Metabolite Annotation}

From the .mgf file obtained from the MZmine treatment, an MN was created using the Feature-Based Molecular Networking workflow [13] on the GNPS platform (https:/ / gnps.ucsdhttps://gnps.ucsd.edu.edu). The precursor ion mass and the MS/MS fragment ion tolerances were set to 0.02 and $0.05 \mathrm{Da}$, respectively. An $\mathrm{MN}$ was then created where the edges were filtered above a cosine of 0.6 and more than 3 matches' peaks. The edges between two nodes were kept in the network if and only if each of the nodes appeared in each other's respective top 10 most similar nodes. The molecular family size was set to a maximum of 100. The spectra in the network were searched against the GNPS spectral libraries [90]. The work is available at the following link, https://gnps.ucsd. $\mathrm{edu} /$ ProteoSAFe/status.jsp?task=9e5e99ef164a4fa0bbe218c73de3ff26. Visualization of the results was carried out in Cytoscape 3.8.0 [91]. The output of the GNPS was used to annotate against the in silico ISDB-DNP [35] and then the script for taxonomically informed metabolite annotation [36] was used to re-rank and clean out the output based on the taxonomy.

\section{Conclusions}

The metabolite profiling workflow based on UHPLC-MS/MS provided a comprehensive survey of the phenolic composition of the methanolic extract of Stryphnodendron pulcherrimum leaves. This workflow identified 30 compounds through spectral matching against experimental data from GNPS. Additionally, 19 compounds were putatively assigned via the same spectral matching but against in silico databases. Compounds $\mathbf{1}$, $4,6,13,24,31,42$ and 45 have been previously reported in the genus Stryphnodendron. Gallic acid (1), (epi)gallocatechin (6), (epi)gallocatechin gallate (13), myricitrin (31) and myricetin (42) were reported previously in the species by our group [49]. To the best of our knowledge, 44 of these compounds are reported herein for the first time in the species Stryphnodendron pulcherrimum and 41 are described for the first time in the genus. The significant and diverse biological activities reported for many of these compounds indicate that this species represents a potentially important biological source of interesting bioactive phenolic compounds.

Supplementary Materials: The following are available online at https://www.mdpi.com/2218-1 989/11/5/281/s1, Compounds annotated in GNPS; Table S1. In-house database including 74 compounds reported in the literature from Stryphnodendron. Figure S1. Matches between spectrum MS/MS from G1. Figure S2. Matches between spectrum MS/MS from G2. Figure S3. Matches between spectrum MS/MS from G3. Figure S4. Fragmentation scheme of (epi)gallocatechin gallate (13). Figure S5. Fragmentation scheme of O-coumaroyl O-galloyl-hexoside (21). Figure S6. Fragmentation scheme of (3,4,5-trihydroxy-6-(4-(1-hydroxypropan-2-yl)-2-methoxyphenoxy)tetrahydro-2H-pyran-2- 
yl)methyl 3,4,5-trihydroxybenzoate (25). Figure S7. Fragmentation scheme of myricitrin (31). Figure S8. Fragmentation scheme of quercitrin (41).

Author Contributions: P.G. designed the studies and conducted LC-MS experiments: L.Q.-G. conducted data treatment, FBMN-GNPS and ISDB identification. P.G. and L.Q.-G. wrote the manuscript. C.S., S.P., J.A.B., M.E., M.S. and J.-L.W. reviewed the whole manuscript. All authors have read and agreed to the published version of the manuscript.

Funding: Conselho Nacional de Desenvolvimento Científico e Tecnológico (CNPq). Process: 141680/20180, Modality: Doctoral Scholarship_GD Graduate Program.

Institutional Review Board Statement: Not applicable.

Informed Consent Statement: Not applicable.

Data Availability Statement: All support data used in this study are available from the authors.

Acknowledgments: P.W.P.G. is thankful to the Conselho Nacional de Desenvolvimento Científico e Tecnológico (CNPq). Process: 141680/2018-0, Modality: Doctoral Scholarship-GD Graduate Program. L.M.Q.G. is thankful to the Ministerio de Ciencia, Tecnología y Telecomunicaciones, MICITT, from Costa Rica for the scholarship provided ( $\mathrm{N}^{\circ}$ 214171-025).

Conflicts of Interest: We declare no current or potential conflict of interest related to this article.

\section{References}

1. Silva, C.A.; Teixeira, A.L.; Rocha, R.O.; Baptista, A.C.; da Silva, A.A.S. Effect of temperature and pre-germination treatments on seed germination of juerana branca (Stryphnodendron pulcherrimum). Afr. J. AIDS Res. 2015, 10, 494-498. [CrossRef]

2. Gonçalves, D.C.M.; de Gama, J.R.V.; de Oliveira, F.A.; de Junior, R.C.O.; Araujo, G.C.; de Almeida, L.S. Aspectos Mercadológicos dos Produtos não Madeireiros na Economia de Santarém-Pará, Brasil. Aspectos Mercadológicos dos Produtos não Madeireiros na Economia de Santarém-Pará Brasil 2012, 19, 9-16. [CrossRef]

3. De Castilho, A.L.; da Silva, J.P.C.; Saraceni, C.H.C.; Díaz, I.E.C.; Paciencia, M.L.B.; Varella, A.D.; Suffredini, I.B. In vitro activity of Amazon plant extracts against Enterococcus faecalis. Braz. J. Microbiol. 2014, 45, 769-779. [CrossRef] [PubMed]

4. Newman, D.J.; Cragg, G.M. Natural Products as Sources of New Drugs from 1981 to 2014. J. Nat. Prod. 2016, 79, 629-661. [CrossRef] [PubMed]

5. Newman, D.J.; Cragg, G.M. Natural products as sources of new drugs over the last 25 years. J. Nat. Prod. 2007, 70, 461-477. [CrossRef]

6. Newman, D.J.; Cragg, G.M. Natural products as sources of new drugs over the 30 years from 1981 to 2010. J. Nat. Prod. 2012, 75, 311-335. [CrossRef]

7. Lautié, E.; Russo, O.; Ducrot, P.; Boutin, J.A. Unraveling Plant Natural Chemical Diversity for Drug Discovery Purposes. Front. Pharmacol. 2020, 11, 397. [CrossRef] [PubMed]

8. Ross, I.A. Medicinal Plants of the World: Volume 1: Chemical Constituents, Traditional and Modern Medicinal Uses; Humana Press: New York, NY, USA, 2010; ISBN 9781617374692.

9. Ross, I.A. Medicinal Plants of the World: Chemical Constituents, Traditional and Modern Medicinal Uses, Volume 2; Humana Press: New York, NY, USA, 2013; ISBN 9781468497069.

10. Spraker, J.E.; Luu, G.T.; Sanchez, L.M. Imaging mass spectrometry for natural products discovery: A review of ionization methods. Nat. Prod. Rep. 2020, 37, 150-162. [CrossRef]

11. Liu, M.; Quinn, R.J. Fragment-based screening with natural products for novel anti-parasitic disease drug discovery. Expert Opin. Drug Discov. 2019, 14, 1283-1295. [CrossRef] [PubMed]

12. Yoon, D.; Choi, B.-R.; Ma, S.; Lee, J.W.; Jo, I.-H.; Lee, Y.-S.; Kim, G.-S.; Kim, S.; Lee, D.Y. Metabolomics for Age Discrimination of Ginseng Using a Multiplex Approach to HR-MAS NMR Spectroscopy, UPLC-QTOF/MS, and GC × GC-TOF/MS. Molecules 2019, 24, 2381. [CrossRef]

13. Nothias, L.F.; Petras, D.; Schmid, R.; Dührkop, K.; Rainer, J.; Sarvepalli, A.; Protsyuk, I.; Ernst, M.; Tsugawa, H.; Fleischauer, M.; et al. Feature-based Molecular Networking in the GNPS Analysis Environment. Nat. Methods 2020, 17, 905-908. [CrossRef]

14. De Mello, J.P.; Petereit, F.; Nahrstedt, A. Flavan-3-ols and prodelphinidins from Stryphnodendron adstringens. Phytochemistry 1996, 41, 807-813. [CrossRef]

15. Palazzo de Mello, J.; Petereit, F.; Nahrstedt, A. Prorobinetinidins from Stryphnodendron adstringens. Phytochemistry 1996, 42, 857-862. [CrossRef]

16. Ishida, K.; de Mello, J.C.P.; Cortez, D.A.G.; Filho, B.P.D.; Ueda-Nakamura, T.; Nakamura, C.V. Influence of tannins from Stryphnodendron adstringens on growth and virulence factors of Candida albicans. J. Antimicrob. Chemother. 2006, 58, 942-949. [CrossRef] [PubMed]

17. Lopes, G.C.; Vieira Machado, F.A.; Mendes de Toledo, C.E.; Sakuragui, C.M.; Palazzo de Mello, J.C. Chemotaxonomic significance of 5-deoxyproanthocyanidins in Stryphnodendron species. Biochem. Syst. Ecol. 2008, 36, 925-931. [CrossRef] 
18. Lima, J.C.S.; Martins, D.T.O.; de Souza, P.T., Jr. Experimental evaluation of stem bark of Stryphnodendron adstringens (Mart.) Coville for antiinflammatory activity. Phytother. Res. 1998, 12, 218-220. [CrossRef]

19. Lopes, G.C.; Sanches, A.C.C.; Nakamura, C.V.; Dias Filho, B.P.; Hernandes, L.; de Mello, J.C.P. Influence of extracts of Stryphnodendron polyphyllum Mart. and Stryphnodendron obovatum Benth. on the cicatrisation of cutaneous wounds in rats. J. Ethnopharmacol. 2005, 99, 265-272. [CrossRef]

20. Costa, M.A.; Ishida, K.; Kaplum, V.; Koslyk, E.D.A.; de Mello, J.C.P.; Ueda-Nakamura, T.; Dias Filho, B.P.; Nakamura, C.V. Safety evaluation of proanthocyanidin polymer-rich fraction obtained from stem bark of Stryphnodendron adstringens (BARBATIMAO) for use as a pharmacological agent. Regul. Toxicol. Pharmacol. 2010, 58, 330-335. [CrossRef]

21. Pereira, E.M.; Gomes, R.T.; Freire, N.R.; Aguiar, E.G.; Brandão, M.d.G.L.; Santos, V.R. In vitro antimicrobial activity of Brazilian medicinal plant extracts against pathogenic microorganisms of interest to dentistry. Planta Med. 2011, 77, 401-404. [CrossRef] [PubMed]

22. De Oliveira, D.R.; Ferreira Júnior, W.S.; de Bitu, V.C.N.; Pinheiro, P.G.; Menezes, C.D.A.; de Brito Junior, F.E.; de Albuquerque, U.P.; Kerntopf, M.R.; Coutinho, H.D.M.; Fachinetto, R.; et al. Ethnopharmacological study of Stryphnodendron rotundifoliumin two communities in the semi-arid region of northeastern Brazil. Rev. Bras. Farmacogn. 2014, 24, 124-132. [CrossRef]

23. Ribeiro, T.G.; Nascimento, A.M.; Henriques, B.O.; Chávez-Fumagalli, M.A.; Franca, J.R.; Duarte, M.C.; Lage, P.S.; Andrade, P.H.R.; Lage, D.P.; Rodrigues, L.B.; et al. Antileishmanial activity of standardized fractions of Stryphnodendron obovatum (Barbatimão) extract and constituent compounds. J. Ethnopharmacol. 2015, 165, 238-242. [CrossRef]

24. Pinto, S.C.G.; Bueno, F.G.; Panizzon, G.P.; Morais, G.; Dos Santos, P.V.P.; Baesso, M.L.; de Leite-Mello, E.V.S.; de Mello, J.C.P. Stryphnodendron adstringens: Clarifying Wound Healing in Streptozotocin-Induced Diabetic Rats. Planta Med. 2015, 81, 1090-1096. [CrossRef]

25. Vandesmet, V.C.S.; Felipe, C.F.B.; Kerntopf, M.R.; Rolón, M.; Vega, C.; Coronel, C.; Barbosa, A.G.R.; Coutinho, H.D.M.; Menezes, I.R.A. The use of herbs against neglected diseases: Evaluation of in vitro leishmanicidal and trypanocidal activity of Stryphnodendron rotundifolium Mart. Saudi J. Biol. Sci. 2017, 24, 1136-1141. [CrossRef]

26. Penido, A.B.; De Morais, S.M.; Ribeiro, A.B.; Alves, D.R.; Rodrigues, A.L.M.; dos Santos, L.H.; de Menezes, J.E.S.A. Medicinal Plants from Northeastern Brazil against Alzheimer's Disease. Evid. Based. Complement. Alternat. Med. 2017, 2017. [CrossRef]

27. De Freitas, A.L.D.; Kaplum, V.; Rossi, D.C.P.; da Silva, L.B.R.; de Melhem, M.S.C.; Taborda, C.P.; de Mello, J.C.P.; Nakamura, C.V.; Ishida, K. Proanthocyanidin polymeric tannins from Stryphnodendron adstringens are effective against Candida spp. isolates and for vaginal candidiasis treatment. J. Ethnopharmacol. 2018, 216, 184-190. [CrossRef]

28. Trevisan, D.A.C.; da Silva, P.V.; Farias, A.B.P.; Campanerut-Sá, P.A.Z.; Ribeiro, T.D.V.R.; Faria, D.R.; de Mendonça, P.S.B.; de Mello, J.C.P.; Seixas, F.A.V.; Mikcha, J.M.G. Antibacterial activity of Barbatimão (Stryphnodendron adstringens) against Staphylococcus aureus: In vitro and in silico studies. Lett. Appl. Microbiol. 2020, 71, 259-271. [CrossRef]

29. Giffoni de Carvalho, J.T.; Henao Agudelo, J.S.; Baldivia, D.D.S.; Carollo, C.A.; Silva, D.B.; de Picoli Souza, K.; Saraiva Câmara, N.O.; Dos Santos, E.L. Hydroethanolic stem bark extracts of Stryphnodendron adstringens impair M1 macrophages and promote M2 polarization. J. Ethnopharmacol. 2020, 254, 112684. [CrossRef]

30. Tasdemir, D.; Lack, G.; Brun, R.; Rüedi, P.; Scapozza, L.; Perozzo, R. Inhibition of Plasmodium falciparum fatty acid biosynthesis: Evaluation of FabG, FabZ, and FabI as drug targets for flavonoids. J. Med. Chem. 2006, 49, 3345-3353. [CrossRef]

31. Scalbert, A. Antimicrobial properties of tannins. Phytochemistry 1991, 30, 3875-3883. [CrossRef]

32. Carvalho, C.P.; Carvalho, T.C.; Eberlin, M.N. Molecular ion: A more contemporary definition. J. Mass Spectrom. 2020, 55, e4598. [CrossRef]

33. Pluskal, T.; Castillo, S.; Villar-Briones, A.; Oresic, M. MZmine 2: Modular framework for processing, visualizing, and analyzing mass spectrometry-based molecular profile data. BMC Bioinform. 2010, 11, 395. [CrossRef]

34. Wang, M.; Carver, J.J.; Phelan, V.V.; Sanchez, L.M.; Garg, N.; Peng, Y.; Nguyen, D.D.; Watrous, J.; Kapono, C.A.; Luzzatto-Knaan, T.; et al. Sharing and community curation of mass spectrometry data with Global Natural Products Social Molecular Networking. Nat. Biotechnol. 2016, 34, 828-837. [CrossRef]

35. Allard, P.M.; Péresse, T.; Bisson, J.; Gindro, K.; Marcourt, L.; Pham, V.C.; Roussi, F.; Litaudon, M.; Wolfender, J.L. Integration of Molecular Networking and In-Silico MS/MS Fragmentation for Natural Products Dereplication. Anal. Chem. 2016, 88, 3317-3323. [CrossRef]

36. Rutz, A.; Dounoue-Kubo, M.; Ollivier, S.; Bisson, J.; Bagheri, M.; Saesong, T.; Ebrahimi, S.N.; Ingkaninan, K.; Wolfender, J.L.; Allard, P.M. Taxonomically Informed Scoring Enhances Confidence in Natural Products Annotation. Front. Plant Sci. 2019, 10, 1-15. [CrossRef]

37. Yokosuka, A.; Okabe, G.; Tatsuno, S.; Mimaki, Y. Stryphnosides G-P, 10 new triterpene glycosides from the pericarps of Stryphnodendron fissuratum. Carbohydr. Res. 2016, 434, 18-26. [CrossRef]

38. Yokosuka, A.; Kawakami, S.; Haraguchi, M.; Mimaki, Y. Stryphnosides A-F, six new triterpene glycosides from the pericarps of Stryphnodendron fissuratum. Tetrahedron 2008, 64, 1474-1481. [CrossRef]

39. Tursch, B.; Tursch, E.; Harrison, I.T.; Silva, G.B.C.T.D.C.B.D.; Monteiro, H.J.; Gilbert, B.; Mors, W.B.; Djerassi, C. Terpenoids. LIII.1a Demonstration of Ring Conformational Changes in Triterpenes of the $\beta$-Amyrin Class Isolated from Stryphnodendron coriaceum. J. Org. Chem. 1963, 28, 2390-2394. [CrossRef]

40. Palazzo de Mello, J.C.; Petereit, F.; Nahrstedt, A. A dimeric proanthocyanidin from Stryphnodendron adstringens. Phytochemistry 1999, 51, 1105-1107. [CrossRef] 
41. do Nascimento, A.M.; Guedes, P.T.; Castilho, R.O.; Vianna-Soares, C.D. Stryphnodendron adstringens (Mart.) Coville (Fabaceae) proanthocyanidins quantitation by RP-HPLC. Braz. J. Pharm. Sci. 2013, 49, 549-558. [CrossRef]

42. Da Costa, J.G.M.; de Leite, G.O.; Dubois, A.F.; Seeger, R.L.; Boligon, A.A.; Athayde, M.L.; Campos, A.R.; da Rocha, J.B.T. Antioxidant effect of Stryphnodendron rotundifolium Martius extracts from Cariri-Ceará State (Brazil): Potential involvement in its therapeutic use. Molecules 2012, 17, 934-950. [CrossRef]

43. Santos, S.C.; Costa, W.F.; Ribeiro, J.P.; Guimarães, D.O.; Ferri, P.H.; Ferreira, H.D.; Seraphin, J.C. Tannin composition of barbatimão species. Fitoterapia 2002, 73, 292-299. [CrossRef]

44. Henriques, B.O.; Corrêa, O.; Azevedo, E.P.C.; Pádua, R.M.; de Oliveira, V.L.S.; Oliveira, T.H.C.; Boff, D.; Dias, A.C.F.; de Souza, D.G.; Amaral, F.A.; et al. In Vitro TNF- Inhibitory Activity of Brazilian Plants and Anti-Inflammatory Effect of Stryphnodendron adstringens in an Acute Arthritis Model. Evid. Based. Complement. Alternat. Med. 2016, 2016, 9872598. [CrossRef]

45. Felipe, A.M.M.; Rincão, V.P.; Benati, F.J.; Linhares, R.E.C.; Galina, K.J.; de Toledo, C.E.M.; Lopes, G.C.; de Mello, J.C.P.; Nozawa, C. Antiviral effect of Guazuma ulmifolia and Stryphnodendron adstringens on poliovirus and bovine herpesvirus. Biol. Pharm. Bull. 2006, 29, 1092-1095. [CrossRef]

46. Sousa, J.N.; Pedroso, N.B.; Borges, L.L.; Oliveira, G.A.R.; Paula, J.R.; Conceição, E.C. Optimization of Ultrasound-assisted extraction of polyphenols, tannins and epigallocatechin gallate from barks of Stryphnodendron adstringens (Mart.) Coville bark extracts. Pharmacogn. Mag. 2014, 10, S318-S323. [CrossRef] [PubMed]

47. Oliveira, D.A.J.; Amaral, J.G.; Garcia, L.B.; Dos Santos, M.S.; Silva, L.A.O.; Almeida, M.P.; Gomes, A.F.; Barros, D.R.P.; Lopes, N.P.; Pereira, G.R.; et al. Associating chitosan and microemulsion as a topical vehicle for the administration of herbal medicines. Carbohydr. Polym. 2021, 255, 117482. [CrossRef]

48. Kind, T.; Fiehn, O. Seven Golden Rules for heuristic filtering of molecular formulas obtained by accurate mass spectrometry. BMC Bioinform. 2007, 8, 105. [CrossRef]

49. Joseph, R.C.; Silva da Fonseca Diniz, M.; Magno do Nascimento, V.; de Barbosa Muribeca, A.J.; Costa Santiago, J.C.; da Cunha Borges, L.; da Costa Sá, P.R.; Portal Gomes, P.W.; da Silva Cardoso, J.C.; Rocha de Castro, M.N.; et al. Secure and Sustainable Sourcing of Plant Tissues for the Exhaustive Exploration of Their Chemodiversity. Molecules 2020, 25, 5992. [CrossRef] [PubMed]

50. Li, C.; Seeram, N.P. Ultra-fast liquid chromatography coupled with electrospray ionization time-of-flight mass spectrometry for the rapid phenolic profiling of red maple (Acer rubrum) leaves. J. Sep. Sci. 2018, 41, 2331-2346. [CrossRef] [PubMed]

51. Sinosaki, N.B.M.; Tonin, A.P.P.; Ribeiro, M.A.S.; Poliseli, C.B.; Roberto, S.B.; da Silveira, R.; Visentainer, J.V.; Santos, O.O.; Meurer, E.C. Structural Study of Phenolic Acids by Triple Quadrupole Mass Spectrometry with Electrospray Ionization in Negative Mode and H/D Isotopic Exchange. J. Braz. Chem. Soc. 2020, 31, 402-408. [CrossRef]

52. Barnaba, C.; Dellacassa, E.; Nicolini, G.; Nardin, T.; Serra, M.; Larcher, R. Non-targeted glycosidic profiling of international wines using neutral loss-high resolution mass spectrometry. J. Chromatogr. A 2018, 1557, 75-89. [CrossRef]

53. Li, H.-J.; Deinzer, M.L. Tandem Mass Spectrometry for Sequencing Proanthocyanidins. Anal. Chem. 2007, 79, 1739-1748. [CrossRef] [PubMed]

54. Quirós-Guerrero, L.; Albertazzi, F.; Araya-Valverde, E.; Romero, R.M.; Villalobos, H.; Poveda, L.; Chavarría, M.; Tamayo-Castillo, G. Phenolic variation among Chamaecrista nictitans subspecies and varieties revealed through UPLC-ESI(-)-MS/MS chemical fingerprinting. Metabolomics 2019, 15, 14. [CrossRef] [PubMed]

55. Davis, B.D.; Brodbelt, J.S. An investigation of the homolytic saccharide cleavage of deprotonated flavonol 3-O-glycosides in a quadrupole ion trap mass spectrometer. J. Mass Spectrom. 2008, 43, 1045-1052. [CrossRef]

56. Hvattum, E.; Ekeberg, D. Study of the collision-induced radical cleavage of flavonoid glycosides using negative electrospray ionization tandem quadrupole mass spectrometry. J. Mass Spectrom. 2003, 38, 43-49. [CrossRef]

57. Demarque, D.P.; Crotti, A.E.M.; Vessecchi, R.; Lopes, J.L.C.; Lopes, N.P. Fragmentation reactions using electrospray ionization mass spectrometry: An important tool for the structural elucidation and characterization of synthetic and natural products. Nat. Prod. Rep. 2016, 33, 432-455. [CrossRef] [PubMed]

58. Yao, L.H.; Jiang, Y.M.; Shi, J.; Tomás-Barberán, F.A.; Datta, N.; Singanusong, R.; Chen, S.S. Flavonoids in food and their health benefits. Plant Foods Hum. Nutr. 2004, 59, 113-122. [CrossRef] [PubMed]

59. Aron, P.M.; Kennedy, J.A. Flavan-3-ols: Nature, occurrence and biological activity. Mol. Nutr. Food Res. 2008, 52, 79-104. [CrossRef] [PubMed]

60. Singh, A.; Kumar, S.; Kumar, B. LC-MS Identification of Proanthocyanidins in Bark and Fruit of six Terminalia species. Nat. Prod. Commun. 2018, 13, 1934578X1801300511. [CrossRef]

61. Fabre, N.; Rustan, I.; de Hoffmann, E.; Quetin-Leclercq, J. Determination of flavone, flavonol, and flavanone aglycones by negative ion liquid chromatography electrospray ion trap mass spectrometry. J. Am. Soc. Mass Spectrom. 2001, 12, 707-715. [CrossRef]

62. Gürler, S.B.; Kiraz, Y.; Baran, Y. Chapter 21-Flavonoids in cancer therapy: Current and future trends. In Biodiversity and Biomedicine; Ozturk, M., Egamberdieva, D., Pešić, M., Eds.; Academic Press: Cambridge, MA, USA, 2020; pp. 403-440, ISBN 9780128195413.

63. Hostetler, G.L.; Ralston, R.A.; Schwartz, S.J. Flavones: Food Sources, Bioavailability, Metabolism, and Bioactivity. Adv. Nutr. 2017, 8, 423-435. [CrossRef] [PubMed]

64. Buzzini, P.; Arapitsas, P.; Goretti, M.; Branda, E.; Turchetti, B.; Pinelli, P.; Ieri, F.; Romani, A. Antimicrobial and antiviral activity of hydrolysable tannins. Mini Rev. Med. Chem. 2008, 8, 1179-1187. [CrossRef] 
65. Ow, Y.-Y.; Stupans, I. Gallic acid and gallic acid derivatives: Effects on drug metabolizing enzymes. Curr. Drug Metab. 2003, 4, 241-248. [CrossRef]

66. Verma, S.; Singh, A.; Mishra, A. Gallic acid: Molecular rival of cancer. Environ. Toxicol. Pharmacol. 2013, 35, 473-485. [CrossRef]

67. Kroes, B.H.; van den Berg, A.J.; Quarles van Ufford, H.C.; van Dijk, H.; Labadie, R.P. Anti-inflammatory activity of gallic acid. Planta Med. 1992, 58, 499-504. [CrossRef] [PubMed]

68. Fernandez, S.P.; Nguyen, M.; Yow, T.T.; Chu, C.; Johnston, G.A.R.; Hanrahan, J.R.; Chebib, M. The flavonoid glycosides, myricitrin, gossypin and naringin exert anxiolytic action in mice. Neurochem. Res. 2009, 34, 1867-1875. [CrossRef] [PubMed]

69. Shen, Y.; Shen, X.; Cheng, Y.; Liu, Y. Myricitrin pretreatment ameliorates mouse liver ischemia reperfusion injury. Int. Immunopharmacol. 2020, 89, 107005. [CrossRef]

70. He, N.; Wang, P.; Niu, Y.; Chen, J.; Li, C.; Kang, W.-Y. Evaluation antithrombotic activity and action mechanism of myricitrin. Ind. Crops Prod. 2019, 129, 536-541. [CrossRef]

71. Yan, Z.; Lin, Z.; Wu, Y.; Zhan, J.; Qi, W.; Lin, J.; Shen, J.; Xue, X.; Pan, X. The protective effect of myricitrin in osteoarthritis: An in vitro and in vivo study. Int. Immunopharmacol. 2020, 84, 106511. [CrossRef] [PubMed]

72. Domitrović, R.; Rashed, K.; Cvijanović, O.; Vladimir-Knežević, S.; Škoda, M.; Višnić, A. Myricitrin exhibits antioxidant, antiinflammatory and antifibrotic activity in carbon tetrachloride-intoxicated mice. Chem. Biol. Interact. 2015, 230, 21-29. [CrossRef]

73. Zhang, B.; Shen, Q.; Chen, Y.; Pan, R.; Kuang, S.; Liu, G.; Sun, G.; Sun, X. Myricitrin Alleviates Oxidative Stress-induced Inflammation and Apoptosis and Protects Mice against Diabetic Cardiomyopathy. Sci. Rep. 2017, 7, 44239. [CrossRef]

74. Dewick, P.M. Medicinal Natural Products: A Biosynthetic Approach; Wiley: Hoboken, NJ, USA, 2009; ISBN 9780470741689.

75. Wan, S.B.; Landis-Piwowar, K.R.; Kuhn, D.J.; Chen, D.; Dou, Q.P.; Chan, T.H. Structure-activity study of epi-gallocatechin gallate (EGCG) analogs as proteasome inhibitors. Bioorg. Med. Chem. 2005, 13, 2177-2185. [CrossRef] [PubMed]

76. Jeong, K.-H.; Cho, S.-Y.; Hong, Y.-D.; Chung, J.-O.; Kim, K.-S.; Shim, S.-M. Transport of gallocatechin gallate and catechin gallate in high-temperature-processed green tea extract from gastrointestinal tract to brain by an in vitro bio-mimic model system coupled with sequential cell cultures. J. Funct. Foods 2018, 47, 83-90. [CrossRef]

77. Nakayama, M.; Shimatani, K.; Ozawa, T.; Shigemune, N.; Tomiyama, D.; Yui, K.; Katsuki, M.; Ikeda, K.; Nonaka, A.; Miyamoto, T. Mechanism for the antibacterial action of epigallocatechin gallate (EGCg) on Bacillus subtilis. Biosci. Biotechnol. Biochem. 2015, 79, 845-854. [CrossRef]

78. Steinmann, J.; Buer, J.; Pietschmann, T.; Steinmann, E. Anti-infective properties of epigallocatechin-3-gallate (EGCG), a component of green tea. Br. J. Pharmacol. 2013, 168, 1059-1073. [CrossRef] [PubMed]

79. Li, F.; Qasim, S.; Li, D.; Dou, Q.P. Updated review on green tea polyphenol epigallocatechin-3-gallate as a cancer epigenetic regulator. Semin. Cancer Biol. 2021. [CrossRef] [PubMed]

80. Sharifi-Rad, M.; Pezzani, R.; Redaelli, M.; Zorzan, M.; Imran, M.; Ahmed Khalil, A.; Salehi, B.; Sharopov, F.; Cho, W.C.; Sharifi-Rad, J. Preclinical Pharmacological Activities of Epigallocatechin-3-gallate in Signaling Pathways: An Update on Cancer. Molecules 2020, 25, 467. [CrossRef]

81. De Sousa-Fontoura, D.M.N.; Olinda, R.G.; Viana, G.A.; de Costa, K.M.F.M.; Batista, J.S.; Serrano, R.M.O.T.; Silva, O.M.D.; Camara, C.A.; Silva, T.M.S. Wound healing activity and chemical composition of geopropolis from Melipona subnitida. Rev. Bras. Farmacogn. 2020, 30, 367-373. [CrossRef]

82. Santos, H.F.D.; Campos, J.F.; Santos, C.M.D.; Balestieri, J.B.P.; Silva, D.B.; Carollo, C.A.; de Picoli Souza, K.; Estevinho, L.M.; Dos Santos, E.L. Chemical Profile and Antioxidant, Anti-Inflammatory, Antimutagenic and Antimicrobial Activities of Geopropolis from the Stingless Bee Melipona orbignyi. Int. J. Mol. Sci. 2017, 18, 953. [CrossRef]

83. Wang, J.-B.; Qin, Y.; Kong, W.-J.; Wang, Z.-W.; Zeng, L.-N.; Fang, F.; Jin, C.; Zhao, Y.-L.; Xiao, X.-H. Identification of the antidiarrhoeal components in official rhubarb using liquid chromatography-tandem mass spectrometry. Food Chem. 2011, 129, 1737-1743. [CrossRef]

84. Banerjee, P.; Erehman, J.; Gohlke, B.-O.; Wilhelm, T.; Preissner, R.; Dunkel, M. Super Natural II-A database of natural products. Nucleic Acids Res. 2014, 43, D935-D939. [CrossRef]

85. Oh, T.W.; Do, H.J.; Jeon, J.-H.; Kim, K. Quercitrin inhibits platelet activation in arterial thrombosis. Phytomedicine 2021, 80, 153363. [CrossRef]

86. Dönder, Y.; Arikan, T.B.; Baykan, M.; Akyüz, M.; Öz, A.B. Effects of quercitrin on bacterial translocation in a rat model of experimental colitis. Asian J. Surg. 2018, 41, 543-550. [CrossRef]

87. Cincin, Z.B.; Unlu, M.; Kiran, B.; Bireller, E.S.; Baran, Y.; Cakmakoglu, B. Molecular mechanisms of quercitrin-induced apoptosis in non-small cell lung cancer. Arch. Med. Res. 2014, 45, 445-454. [CrossRef]

88. Lee, K.S.; Park, S.N. Cytoprotective effects and mechanisms of quercetin, quercitrin and avicularin isolated from Lespedeza cuneata G. Don against ROS-induced cellular damage. J. Ind. Eng. Chem. 2019, 71, 160-166. [CrossRef]

89. Chambers, M.C.; MacLean, B.; Burke, R.; Amodei, D.; Ruderman, D.L.; Neumann, S.; Gatto, L.; Fischer, B.; Pratt, B.; Egertson, J.; et al. A cross-platform toolkit for mass spectrometry and proteomics. Nat. Biotechnol. 2012, 30, 918-920. [CrossRef] [PubMed]

90. Horai, H.; Arita, M.; Kanaya, S.; Nihei, Y.; Ikeda, T.; Suwa, K.; Ojima, Y.; Tanaka, K.; Tanaka, S.; Aoshima, K.; et al. MassBank: A public repository for sharing mass spectral data for life sciences. J. Mass Spectrom. 2010, 45, 703-714. [CrossRef]

91. Shannon, P.; Markiel, A.; Ozier, O.; Baliga, N.S.; Wang, J.T.; Ramage, D.; Amin, N.; Schwikowski, B.I. Cytoscape: A Software Environment for Integrated Models. Genome Res. 2003, 13, 2498-2504. [CrossRef] [PubMed] 